\title{
Animal models for human contiguous gene syndromes and other genomic disorders
}

\author{
Katherina Walz ${ }^{1}$, Patricia Fonseca ${ }^{1}$ and James R. Lupski ${ }^{1,2,3}$ \\ ${ }^{1}$ Baylor College of Medicine, Department of Molecular \& Human Genetics, Houston, Texas, USA. \\ ${ }^{2}$ Baylor College of Medicine, Department of Pediatrics, Houston, Texas, USA. \\ ${ }^{3}$ Texas Children's Hospital, Houston, Texas, USA.
}

\begin{abstract}
Genomic disorders refer to a group of syndromes caused by DNA rearrangements, such as deletions and duplications, which result in an alteration of normal gene dosage. The chromosomal rearrangements are usually relatively small and often difficult to detect cytogenetically. In a subset of such conditions the rearrangements comprise multiple unrelated contiguous genes that are physically linked and thus have been referred to as contiguous gene syndromes (CGS). In general, each syndrome presents a complex clinical phenotype that has been attributed generally to dosage sensitive gene(s) present in the responsible chromosomal interval. A common mechanism for CGS resulting from interstitial deletion/duplication has recently been elucidated. The DNA rearrangements result from nonallelic homologous recombination (NAHR) utilizing flanking low-copy repeats (LCRs) as recombination substrates. The resulting rearrangements often involve the same genomic region, a common deletion or duplication, making it difficult to assign a specific phenotype or endophenotype to a single responsible gene. The human and mouse genome sequencing projects, in conjunction with the ability to engineer mouse chromosome rearrangements, have enabled the production of mouse models for CGS and genomic disorders. In this review we present an overview of different techniques utilized to generate mouse models for selected genomic disorders. These models foment novel insights into the specific genes that convey the phenotype by dosage and/or position effects and provide opportunities to explore therapeutic options.
\end{abstract}

Key words: genomic disorders, contiguous gene syndromes, microdeletion, microduplication.

Received: May 20, 2004; Accepted: June 14, 2004.

\section{Contiguous Gene Syndromes and other Genomic Disorders}

The term contiguous gene syndrome (CGS) was first introduced by Schmickel (Schmickel, 1986) to describe disorders associated with specific chromosomal microdeletions whose phenotypic manifestations were due to the involvement of multiple, unrelated genes that are physically linked to each other (Shaffer et al., 2001). CGS are a specific subtype of genomic disorders. The concept of "genomic disorders" refers to conditions that result from DNA rearrangements due to regional DNA architecture (Lupski, 1998). Genomic disorders are a result of recurrent DNA rearrangements involving unstable genomic regions. The genomic rearrangements are usually flanked by low copy repeats (LCR) ranging in size from 10 to $400 \mathrm{~kb}$, that have $>97-98 \%$ sequence identity between them

Send correspondence to James R. Lupski. Baylor College of Medicine, Dept. of Molecular \& Human Genetics, One Baylor Plaza, Room 604B, Houston, TX 77030-34398, U.S.A. E-mail: jlupski@bcm.tmc.edu.
(Stankiewicz and Lupski, 2002). Through the process of non allelic-homologous recombination (NAHR), DNA rearrangements such as deletions, duplications or inversions, are facilitated (Lupski, 1998; Shaffer and Lupski, 2000; Emanuel and Shaikh, 2001; Shaffer et al., 2001; Inoue and Lupski, 2002; Stankiewicz and Lupski, 2002; Lupski, 2003; Shaw and Lupski, 2004).

An increasing number of rearrangement-based disorders have been recognized (Figure 1). The DNA rearrangements are usually small on a cytogenetic scale $(<5 \mathrm{Mb})$, thus molecular technologies, such as PCR, pulsed-field gel electrophoresis (PFGE) and fluorescence in situ hybridization (FISH), are necessary for the identification and diagnosis of several of these disorders. A listing of representative genomic disorders can be found in Table 1; they range from $\mathrm{X}$-linked deletions (that result in structural and functional nullisomy of the genes involved in males), through autosomal deletions (that cause reduction of gene dosage, hence causing structural and functional monosomy, and phenotypes secondary to haploinsufficient genes), to autosomal duplication (giving an increase of gene dosage, 


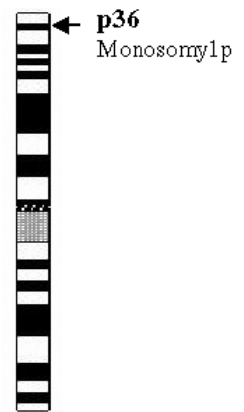

1
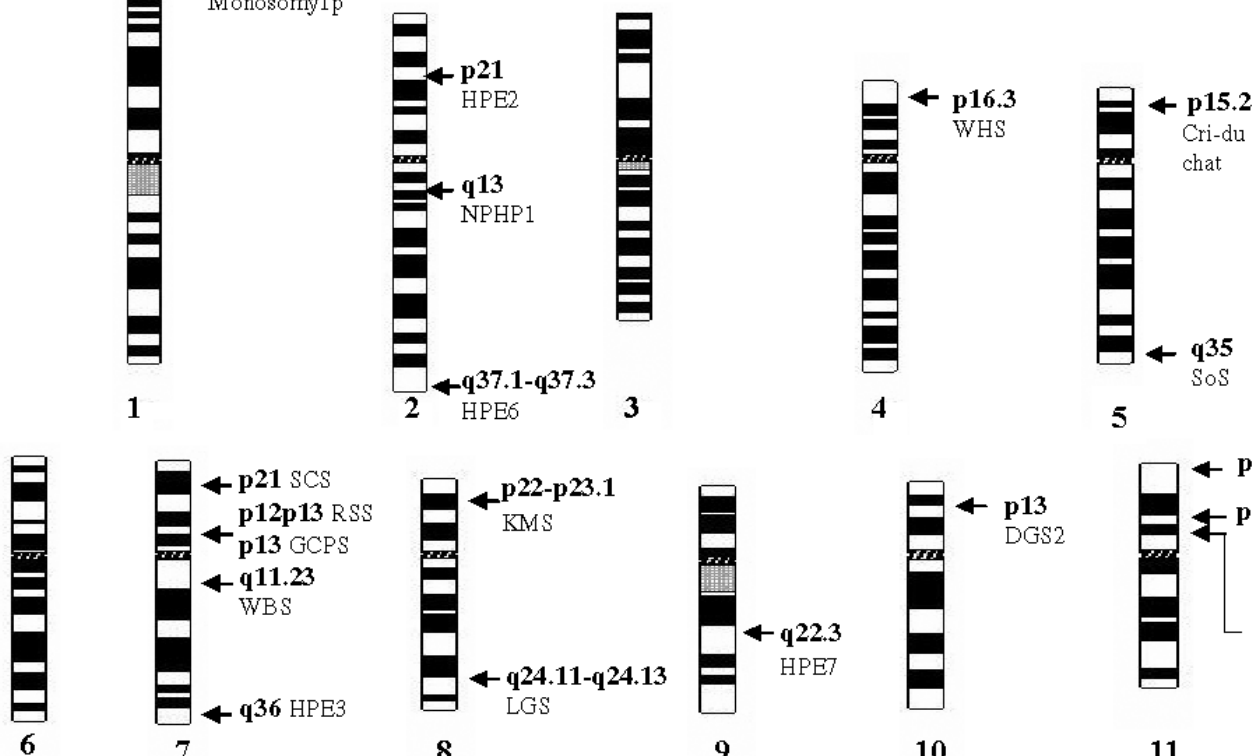

8

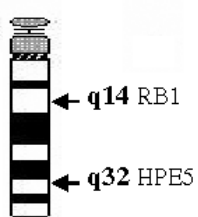

13

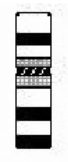

19

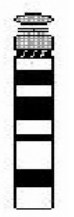

14

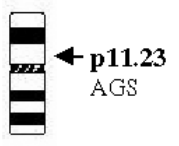

20

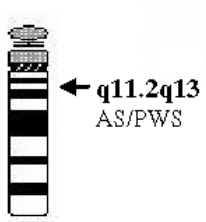

15

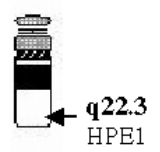

21

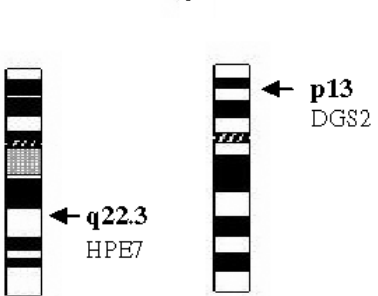

9
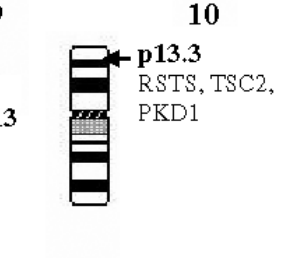

16

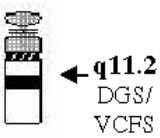

22
5

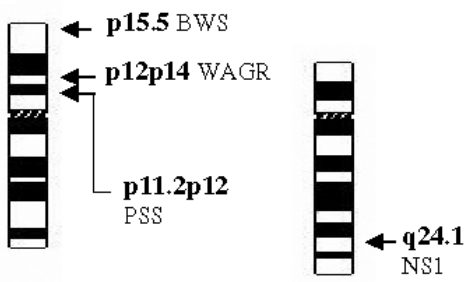

11

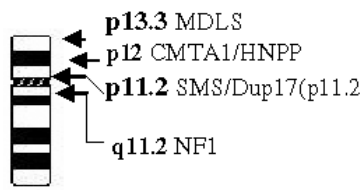

12

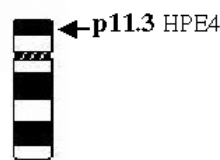

18

17

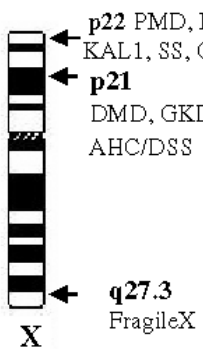

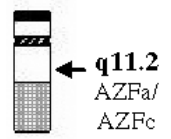

Y

Figure 1 - Genomic disorders. A karyogram representation of human chromosomes, with arrows indicating all the genomic disorders found to date. NPHP1: Nephronophthisis 1, WHS: Wolf-Hirschhorn Syndrome, SoS: Sotos Syndrome, SCS: Saethre-Chotzen Syndrome, RSS: Russell-Silver Syndrome, GCPS: Greig cephalopolysyndactyly Syndrome, WBS: Williams-Beuren Syndrome, KMS: Kabuki Syndrome, LGS: Langer-Giedion Syndrome, BWS: Beckwith-Wiedemann Syndrome, WAGR: Wilms Tumor-Aniridia-Genitourinary Anomalies-Mental Retardation Syndrome, PSS: Potocki-Shaffer Syndrome, NS1: Noonan Syndrome, RB1: Retinoblastoma/MR, AS: Angelman Syndrome, PWS: Prader-Willi Syndrome, RSTS: Rubinstein-Taybi Syndrome, TSC2: Tuberous sclerosis-2, PKD1: Polycystic kidney disease, MDLS: Miller-Dieker Lissencephaly Syndrome, SMS: Smith Magenis Syndrome, CMTA1: Charcot-Marie-Tooth Disease, HNPP: Hereditary Neuropathy with Liability to Pressure Palsies, NF1: Neurofibromatosis I, AGS: Alagille Syndrome, DGS: DiGeorge Syndrome, VCFS: Velocardiofacial Syndrome, DMD: Duchenne Muscular Dystrophy, GKD: Hyperglycerolemia, AHC: Adrenal hypoplasia congenital, DSS: Dosage-Sensitive Sex Reversion, PMD: Pelizaeus-Merzbacher, MLS: Microphtalmia with linear Skin Defects Syndrome, STS: X-linked Ichthyosis, KAL1: Kallmann Syndrome, SS: Short Stature, CDPX1: Chondrodysplasia Punctata, OA1: X-linked ocular Albinism, AZFa/c: Male Infertility, HPE 1-7: Holoprosencephaly locus 1-7.

resulting in structural and functional segmental trisomy). Each syndrome is characterized by a specific and complex phenotype. Some patients lacking the classical rearrangement, but harboring point mutations in a candidate gene prompted the identification of the dosage sensitive gene responsible for some of these disorders. Examples of such single predominant haploinsufficient genes in CGS include: mutations in the transcriptional co-activator CBP for Rubinstein-Taybi syndrome (Petrij, et al., 1995); p57(KIP2) for Beckwith-Wiedemann Syndrome (Hatada et al., 1996); JAG1 for Alagille syndrome (Oda et al., 1997;
Li et al., 1997); UBE3A for Angelman syndrome (Kishino et al., 1997); NSD1 for Sotos (Kurotaki et al., 2002) and RAI1 for Smith-Magenis Syndrome (Slager et al., 2003). Interestingly, several of these genes encode transcription factors, which can potentially explain the pleiotropic phenotypes present in the patients.

Establishing a correlation between each phenotype and the particular gene that is dosage sensitive has often been a major challenge given the facts that the regions involved are usually large (megabases in size) and include several genes. Furthermore, the same size rearrangement 
Table 1 - Contiguous gene syndromes and other genomic disorders.

\begin{tabular}{|c|c|c|c|c|}
\hline Syndrome/Disorder & $\begin{array}{l}\text { Chromosomal } \\
\text { rearrangement }\end{array}$ & OMIM \# & Gene(s) involved & Mouse models \\
\hline monosomy $1 \mathrm{p}$ & $\operatorname{del}(1)(\mathrm{p} 36)$ & 607872 & Possibly SKI, DVL1 & Ski targeted mutagenesis (Berk et al., 1997) \\
\hline Holoprosencephaly 2 (HPE2) & $\operatorname{del}(2)(\mathrm{p} 21 \mathrm{p} 21)$ & 157170 & $S I X 3$ & $\begin{array}{l}\text { Six } 3 \text { locus was inactivated by an in-frame in- } \\
\text { sertion of lacZ (Lagutin et al., 2003) }\end{array}$ \\
\hline Nephronophthisis 1 (NPHP1) & $\operatorname{del}(2)(q 13 q 13)$ & 256100 & NPHP1 & Not available \\
\hline Holoprosencephaly 6 (HPE6) & $\operatorname{del}(2)(\mathrm{q} 37.1 \mathrm{q} 37.3)$ & 605934 & HPE6 & Not available \\
\hline $\begin{array}{l}\text { Wolf-Hirschhorn Syndrome } \\
\text { (WHS) }\end{array}$ & $\operatorname{del}(4)(\mathrm{p} 16.3)$ & 194190 & Unknown & Nested deletions (Näf et al., 2001) \\
\hline Cri-du-chat Syndrome & $\operatorname{del}(5)(\mathrm{p} 15.2)$ & 123450 & Possibly $h T E R T$ & Not available \\
\hline Sotos Syndrome (SoS) & $\operatorname{del}(5)(\mathrm{q} 35 \mathrm{q} 35)$ & 117550 & NSD1 & $\begin{array}{l}\text { Nsd1 targeted mutagenesis (Rayasam et } \\
\text { al., 2003) }\end{array}$ \\
\hline $\begin{array}{l}\text { Saethre-Chotzen Syndrome } \\
\text { (SCS) }\end{array}$ & $\operatorname{del}(7)(\mathrm{p} 21 \mathrm{p} 21)$ & 101400 & TWIST & Twist null mice (Chen, 1995) \\
\hline $\begin{array}{l}\text { Greig cephalopolysyndactyly } \\
\text { Syndrome (GCPS) }\end{array}$ & $\operatorname{del}(7)(\mathrm{p} 13 \mathrm{p} 13)$ & 175700 & GLI3 & $\begin{array}{l}\text { Extra toes (an intragenic deletion of the Gli3 } \\
\text { gene, Hui and Joyner, 1993) }\end{array}$ \\
\hline $\begin{array}{l}\text { Williams-Beuren Syndrome } \\
\text { (WBS) }\end{array}$ & $\operatorname{del}(7)(q 11.23 q 11.23)$ & 194050 & $\begin{array}{l}E L N \text { for supravalvular aortic } \\
\text { stenosis (SVAS); LIMK1 for } \\
\text { impaired visuospatial con- } \\
\text { structive cognition; CYLN2 } \\
\text { for neurodevelopment ab- } \\
\text { normalities? }\end{array}$ & $\begin{array}{l}\text { Eln targeted mutagenesis (Li et al., 1998); } \\
\text { Cyln } 2 \text { targeted mutagenesis (Hoogenraad et } \\
\text { al., 2002); Lim K1 targeted mutagenesis } \\
\text { (Meng et al., 2002) }\end{array}$ \\
\hline Russell-Silver Syndrome (RSS) & $\operatorname{dup}(7)(\mathrm{p} 12 \mathrm{p} 13)$ & 180860 & $\begin{array}{l}\text { Strong evidence for } G R B 10 \\
\text { as a growth suppressor }\end{array}$ & $\begin{array}{l}\text { Grb10 targeted mutagenesis (Charalambous et } \\
\text { al., 2003) }\end{array}$ \\
\hline Holoprosencephaly 3 (HPE3) & $\operatorname{del}(7)(q 36)$ & 142945 & SHH & $\begin{array}{l}\text { Shh targeted mutagenesis (Chiang et } \\
\text { al., 1996) }\end{array}$ \\
\hline Kabuki Syndrome (KMS) & $\operatorname{dup}(8)(\mathrm{p} 22 \mathrm{p} 23.1)$ & 147920 & Unknown & Not available \\
\hline $\begin{array}{l}\text { Langer-Giedion Syndrome } \\
\text { (LGS) }\end{array}$ & $\operatorname{del}(8)(\mathrm{q} 24.11 \mathrm{q} 24.13)$ & 150230 & $\begin{array}{l}\text { EXT1 for exostoses; TRPS1 } \\
\text { for Tricho-Rhino-Phalangeal } \\
\text { Syndrome (TRPS) }\end{array}$ & $\begin{array}{l}\text { Trps } 1 \text { targeted mutagenesis (Malik et } \\
\text { al., 2002); Ext targeted mutagenesis (Lin et } \\
\text { al., 2000) }\end{array}$ \\
\hline Holoprosencephaly 7 (HPE7) & $\operatorname{del}(9)(\mathrm{q} 22.3)$ & 601309 & PTCH & $\begin{array}{l}\text { Ptch targeted mutagenesis (Goodrich et } \\
\text { al., 1997) }\end{array}$ \\
\hline DiGeorge Syndrome 2 (DGS2) & $\operatorname{del}(10)(\mathrm{p} 13)$ & 601362 & & Not Available \\
\hline $\begin{array}{l}\text { Beckwith-Wiedemann Syn- } \\
\text { drome (BWS) }\end{array}$ & $\operatorname{dup}(11)(\mathrm{p} 15.5 \mathrm{p} 15.5)$ & 130650 & p57(KIP2) & $\begin{array}{l}\text { p57(KIP2) targeted mutagenesis (Zhang et } \\
\text { al., 1997) }\end{array}$ \\
\hline $\begin{array}{l}\text { Wilms Tumor- } \\
\text { Aniridia-Genitourinary Anom- } \\
\text { alies-Mental Retardation Syn- } \\
\text { drome (WAGR) }\end{array}$ & $\operatorname{del}(11)(\mathrm{p} 12 \mathrm{p} 14)$ & 194072 & $\begin{array}{l}P A X 6 \text { for aniridia } \\
\text { (AN2), WT1 for and genito- } \\
\text { urinary anomalies }\end{array}$ & $\begin{array}{l}\text { Wt1 targeted mutagenesis (Kreidberg et } \\
\text { al., 1993; Wagner et al., 2002); transgenic } \\
\text { WT1 (Wagner } \text { et al., 2002; Guo et al., 2002); } \\
\text { small eye mouse and rat models (Glaser et } \\
\text { al., 1990; Hill et al., 1991; Matsuo et } \\
\text { al., 1993); Pax6 conditional tissue-specific } \\
\text { targeted mutagenesis (Ashery-Padan } \text { et } \\
\text { al., 2000); Pax6 transgenesis (Schedl et } \\
\text { al., 1996) }\end{array}$ \\
\hline $\begin{array}{l}\text { Potocki-Shaffer Syndrome } \\
\text { (PSS) }\end{array}$ & $\operatorname{del}(11)(\mathrm{p} 11.2 \mathrm{p} 12)$ & 601224 & $\begin{array}{l}E X T 2 ; A L X 4 \text { for parietal } \\
\text { foramina }(\mathrm{PFM})\end{array}$ & Alx4 targeted mutagenesis (Qu et al., 1997) \\
\hline Noonan Syndrome (NS1) & $\operatorname{del}(12)(\mathrm{q} 24.1 \mathrm{q} 24.31)$ & 163950 & PTPN11 & $\begin{array}{l}\text { Targeted mutation Ptpn11(Saxton et } \\
\text { al., 1997) }\end{array}$ \\
\hline Retinoblastoma/MR (RB1) & $\operatorname{del}(13)(q 14 q 14)$ & 180200 & $R B 1$ & Targeted disruption of $R b$ (Lee et at., 1992) \\
\hline Holoprosencephaly 5 (HPE5) & $\operatorname{del}(13)(\mathrm{q} 32 \mathrm{q} 32)$ & 603073 & ZIC2 & Kumba mutant (Elms et al., 2003) \\
\hline Prader-Willi syndrome (PWS) & $\begin{array}{l}\text { paternal } \\
\operatorname{del}(15)(\mathrm{q} 11.2 \mathrm{q} 13)\end{array}$ & 176270 & $\begin{array}{l}\text { Possibly paternal } S N R N P ; P \\
\text { likely for hypopigmentation; } \\
N D N \text { for hypothalamic and } \\
\text { behavioral alterations }\end{array}$ & $\begin{array}{l}\text { Snrpn and imprinting center targeted muta- } \\
\text { genesis (Yang et al., 1998); Ndn targeted mu- } \\
\text { tagenesis (Muscatelli et al., 2000); uniparental } \\
\text { disomy (Cattanach et al., 1992); } \\
\text { transgene-induced deletion (Gabriel et } \\
\text { al., 1999) }\end{array}$ \\
\hline
\end{tabular}


Table 1. (cont.)

\begin{tabular}{|c|c|c|c|c|}
\hline Syndrome/Disorder & $\begin{array}{l}\text { Chromosomal } \\
\text { rearrangement }\end{array}$ & OMIM \# & Gene(s) involved & Mouse models \\
\hline Angelman syndrome (AS) & $\begin{array}{l}\text { maternal } \\
\operatorname{del}(15)(\mathrm{q} 11.2 \mathrm{q} 13)\end{array}$ & 105830 & $\begin{array}{l}U B E 3 A, P \text { for } \\
\text { hypopigmentation }\end{array}$ & $\begin{array}{l}\text { Maternal and paternal Ube } 3 \text { a targeted muta- } \\
\text { genesis (Jiang et al., 1998); uniparental } \\
\text { disomy (Cattanach et al., 1997); } \\
\text { transgene-induced deletion (Gabriel et } \\
\text { al., 1999) }\end{array}$ \\
\hline Tuberous sclerosis-2 (TSC2) & $\operatorname{del}(16)(p 13.3)$ & 191100 & TSC2 & $\begin{array}{l}\text { Germline inactivation of } 1 \text { allele of } T s c 2 \text { gene } \\
\text { (Kleymenova et al., 2001) }\end{array}$ \\
\hline $\begin{array}{l}\text { Polycystic kidney disease } \\
\text { (PKD1) }\end{array}$ & $\operatorname{del}(16)(\mathrm{p} 13.3 \mathrm{p} 13.3)$ & 173900 & $P K D 1$ & $\begin{array}{l}\text { Targeted mutagenesis of } P k d 1 \text { (Lu et } \\
\text { al., 1997) }\end{array}$ \\
\hline $\begin{array}{l}\text { Rubinstein-Taybi Syndrome } \\
\text { (RSTS) }\end{array}$ & $\operatorname{del}(16)(\mathrm{p} 13.3 \mathrm{p} 13.3)$ & 180849 & $C B P$ & $\begin{array}{l}\text { Cbp targeted mutagenesis and truncated pro- } \\
\text { tein (Tanaka et al., 1997; Oike et al., 1999) }\end{array}$ \\
\hline $\begin{array}{l}\text { Miller-Dieker Lissencephaly } \\
\text { Syndrome (MDLS) }\end{array}$ & $\operatorname{del}(17)(\mathrm{p} 13.3)$ & 247200 & $\begin{array}{l}\text { LIS1 for lissencephaly; } \\
\text { 14-3-3-epsilon for defects in } \\
\text { brain development and } \\
\text { neuronal migration }\end{array}$ & $\begin{array}{l}\text { Lis } 1 \text { targeted mutagenesis (Hirotsune } \text { et } \\
\text { al., 1998) and hypomorph (Cahana } \text { et } \\
\text { al., 2001); 14-3-3-epsilon targeted mutagene- } \\
\text { sis (Toyo-oka et al., 2003.) }\end{array}$ \\
\hline $\begin{array}{l}\text { Charcot-Marie-Tooth Disease } \\
\text { (CMT1A) and reciprocal He- } \\
\text { reditary Neuropathy with Lia- } \\
\text { bility to Pressure Palsies } \\
\text { (HNPP) }\end{array}$ & $\begin{array}{l}\operatorname{dup}(17)(\mathrm{p} 12 \mathrm{p} 12) \\
\operatorname{del}(17)(\mathrm{p} 12 \mathrm{p} 12)\end{array}$ & $\begin{array}{l}118220 \\
162500\end{array}$ & $P M P 22$ & $\begin{array}{l}\text { Trembler mouse (Suter et al., 1992); } \\
\text { hypomorph (Maycox et al., 1997); Pmp22 tar- } \\
\text { geted mutagenesis (Adlkofer et al., 1995); } \\
\text { transgenesis (Huxley et al., 1996; Magyar et } \\
\text { al., 1996); inducible Pmp22 overexpression } \\
\text { (Perea } \text { et al., 2001) }\end{array}$ \\
\hline $\begin{array}{l}\text { Smith-Magenis Syndrome } \\
\text { (SMS) }\end{array}$ & $\operatorname{del}(17)(\mathrm{p} 11.2 \mathrm{p} 11.2)$ & 182290 & RAIl for full phenotype? & $\begin{array}{l}\text { Chromosomal engineering (Walz et al., 2003); } \\
\text { nested deletions }\end{array}$ \\
\hline $\operatorname{dup}(17)(\mathrm{p} 11.2 . \mathrm{p} 11.2)$ & $\operatorname{dup}(17)(\mathrm{p} 11.2 . \mathrm{p} 11.2)$ & & $?$ & $\begin{array}{l}\text { Chromosomal engineering (Walz et } \\
\text { al., 2003), transgenesis }\end{array}$ \\
\hline Neurofibromatosis I (NF1) & $\operatorname{del}(17)(\mathrm{q} 11.2 \mathrm{q} 11.2)$ & 162200 & $N F 1$ & $\begin{array}{l}\text { Targeted mutagenesis } N f 1 \text { (Jacks et al., 1994) } \\
\text { (Brannan et al., 1994) Nf1 tissue specific inac- } \\
\text { tivation (Gitler } \text { et al., 2003) }\end{array}$ \\
\hline Holoprosencephaly 4 (HPE4) & $\operatorname{del}(18)(p 11.3)$ & 142946 & $T G I F$ & Not available \\
\hline Alagille Syndrome (AGS) & $\operatorname{del}(20)(\mathrm{p} 12.2 \mathrm{p} 12.2)$ & 118450 & $\begin{array}{l}J A G 1 \text { for eye } \\
\text { dysmorphology }\end{array}$ & $\begin{array}{l}\text { Single and double targeted mutagenesis (Jagl } \\
\text { null and Notch2 hypomorph); (Xue et } \\
\text { al., 1999; McCright et al., 2002) }\end{array}$ \\
\hline Holoprosencephaly 1 (HPE1) & $\operatorname{del}(21)(\mathrm{q} 22.3)$ & 236100 & TMEMI & Not Available \\
\hline $\begin{array}{l}\text { DiGeorge Syn- } \\
\text { drome/Velocardio facial Syn- } \\
\text { drome (DGS/VCFS) }\end{array}$ & $\operatorname{del}(22)(\mathrm{q} 11.2 \mathrm{q} 11.2)$ & 188400 & $T B X 1$ & $\begin{array}{l}\text { Chromosomal engineering (Lindsay et } \\
\text { al., 1999; Merscher } \text { et al., 2001); nested dele- } \\
\text { tions; Tbxl and Crk1 targeted mutagenesis } \\
\text { (Jerome et al., 2001; Guris et al., 2001); } \\
\text { transgenesis (Lindsay et al., 2001; Merscher } \text { et } \\
\text { al., 2001; Funke et al., 2001); Raldh2 } \\
\text { hypomorph (Vermot, 2003) }\end{array}$ \\
\hline $\begin{array}{l}\text { Adrenal hypoplasia congenita } \\
\text { (AHC) and reciprocal Dos- } \\
\text { age-Sensitive Sex Reversion } \\
\text { (DSS) }\end{array}$ & $\begin{array}{l}\operatorname{del}(X)(\mathrm{p} 21 \mathrm{p} 21) \\
\operatorname{dup}(\mathrm{X})(\mathrm{p} 21 \mathrm{p} 21)\end{array}$ & 300200 & $D A X 1$ & $\begin{array}{l}\text { Ahch (homolog of DAX1) targeted mutagene- } \\
\text { sis (Yu et al., 1998); Dax1 transgenesis (Swain } \\
\text { et al., 1998) }\end{array}$ \\
\hline Pelizaeus-Merzbacher (PMD) & $\begin{array}{l}\operatorname{del}(X)(q 22 q 22) \text { and } \\
\operatorname{dup}(X)(q 22 q 22)\end{array}$ & 312080 & $P L P$ & $\begin{array}{l}\text { Jimpy mouse (Dautigny et al., 1986; Nave et } \\
\text { al., 1986; Sidman, 1964); PLP/DMD20 tar- } \\
\text { geted mutagenesis (Klugmann et al., 1997); } \\
\text { PLP transgenesis (Readhead et al., 1994; } \\
\text { Inoue et al., 1996) }\end{array}$ \\
\hline $\begin{array}{l}\text { Microphtalmia with Linear Skin } \\
\text { Defects Syndrome (MLS) }\end{array}$ & $\operatorname{del}(\mathrm{X})(\mathrm{p} 22.31 \mathrm{q} 22.31)$ & 309801 & HSSC for male lethality? & $\begin{array}{l}\text { Chromosome engineering and transgenesis } \\
\text { (Prakash et al., 2002) }\end{array}$ \\
\hline $\begin{array}{l}\text { Duchenne Muscular Dystrophy } \\
\text { (DMD) }\end{array}$ & $\operatorname{del}(\mathrm{X})(\mathrm{p} 21.2 \mathrm{p} 21.2)$ & 310200 & $D M D$ & $\begin{array}{l}\text { Mdx mouse model (Sicinski et al., 1989); in- } \\
\text { ducible transgenesis (Ahmad et al., 2000); } \\
\text { transgenesis (Cox et al., 1993; Phelps et } \\
\text { al., 1995; Rafael et al., 1996; Wells et } \\
\text { al., 1995) }\end{array}$ \\
\hline Hyperglycerolemia (GKD) & $\operatorname{del}(X)(p 21 p 21)$ & 307030 & $G K$ & Gyk targeted mutagenesis (Huq et al., 1997) \\
\hline
\end{tabular}


Table 1. (cont.)

\begin{tabular}{|c|c|c|c|c|}
\hline Syndrome/Disorder & $\begin{array}{l}\text { Chromosomal } \\
\text { rearrangement }\end{array}$ & OMIM \# & Gene(s) involved & Mouse models \\
\hline X-linked Ichthyosis (STS) & $\operatorname{del}(\mathrm{X})(\mathrm{p} 22.3 \mathrm{p} 22.3)$ & 308100 & STS & Not available \\
\hline Kallmann Syndrome (KAL1) & $\operatorname{del}(X)(p 22.3 p 22.3)$ & 308700 & KAL1 & Not available \\
\hline Short Stature (SS) & $\operatorname{del}(\mathrm{X})(\mathrm{p} 22.32)$ & 604271 & SHOX & Not available \\
\hline $\begin{array}{l}\text { X-linked Recessive } \\
\text { Chondrodysplasia Punctata } \\
\text { (CDPX1) }\end{array}$ & $\operatorname{del}(\mathrm{X})(\mathrm{p} 22.3 \mathrm{p} 22.3)$ & 302950 & $A R S E$ & Not available \\
\hline $\begin{array}{l}\text { X-linked Ocular Albinism } \\
\text { (OA1) }\end{array}$ & $\operatorname{del}(\mathrm{X})(\mathrm{p} 22.3 \mathrm{p} 22.3)$ & 300500 & $O A 1$ & Oal targeted mutagenesis (Incerti et al., 2000) \\
\hline Azoospermia (AZFa and $\mathrm{AZFc})$ & $\operatorname{del}(\mathrm{Y})(\mathrm{q} 11.2)$ & 415000 & $D A Z$ & $\begin{array}{l}\text { Dazla targeted mutagenesis (Ruggiu et } \\
\text { al., 1997); complementation transgenesis (Slee } \\
\text { et al., 1999) }\end{array}$ \\
\hline
\end{tabular}

usually occurs in most patients because of the molecular mechanism that results in fixed breakpoints reflecting genome architecture. In cases wherein it was not possible to identify patients harboring varying-sized deletions/duplications, or single gene mutations were not found, or a translocation disrupting a particular gene in the critical region was not available, murine models have proven to be extremely valuable for elucidating the predominant gene(s) responsible for the phenotype. Murine models are also essential for evaluating the effects of modifier loci.

\section{Generation of Chromosome Rearrangements}

The mouse shares physiologic, anatomic and genomic similarities with humans and can be readily manipulated genetically. It has thus become an important animal model for studying human disease. The completion of the sequencing of the human and mouse genomes enables comparative genomic analyses. Many genomic regions between these species maintain conserved syntenic relationships. Chromosomal deletions, duplications, inversions and translocations can be produced in mice using radiation or chemicals mutagens (Russell, 1951; Rinchik et al., 1993). The disadvantage of these methods is that the rearrangements are created at random, without the ability to predetermine their endpoints. Another disadvantage is the relatively large size required for cytogenetic detection, therefore skewing toward a selection of large deletions in gene poor regions of the genome. You et al. (1997) could generate deletions in the genome combining irradiation and ES cell technology. The advantage of this methodology relies on the fact that ES cells are evaluated which reduces the amount of work involving the whole animal. However, since these deletions are still generated at random, a significant amount of work is required for the molecular characterization of each deletion.

Only recently have strategies been developed to introduce defined chromosomal rearrangements in the mouse genome by engineering them in embryonic stem cells (ES) using the Cre-loxP site-specific recombination system.
Allan Bradley and colleagues described the first generation of megabase genomic rearrangements in mice utilizing chromosomal engineering (Ramirez-Solis et al., 1995).

To generate a specific genomic rearrangement between two endpoints, two sequential gene-targeting steps are required in order to prepare each endpoint for selectable Cre-loxP recombination (Ramirez-Solis et al., 1995)(Figures 2 and 3 ). The double-targeted ES cell is then transiently transfected with Cre recombinase (an enzyme that catalyzes site specific recombination between the specific

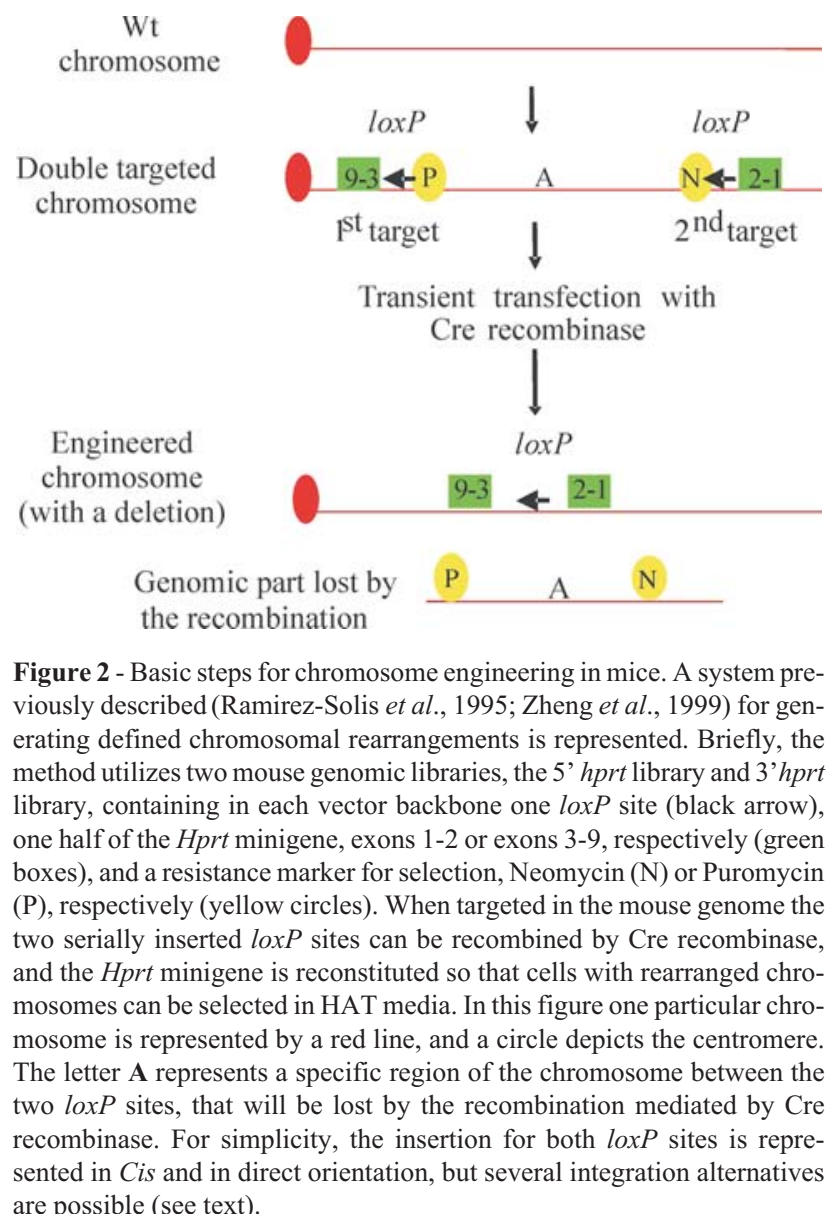
are possible (see text). 

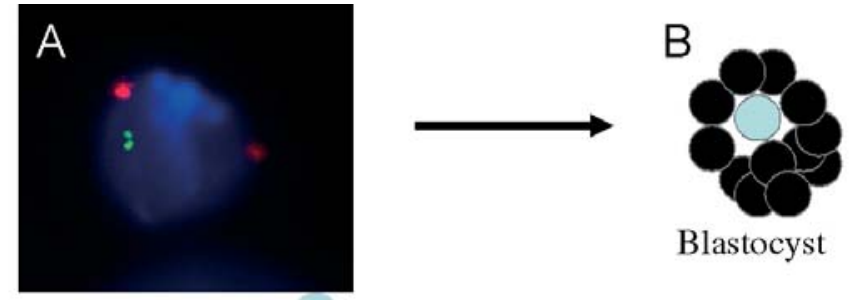

Blastocyst

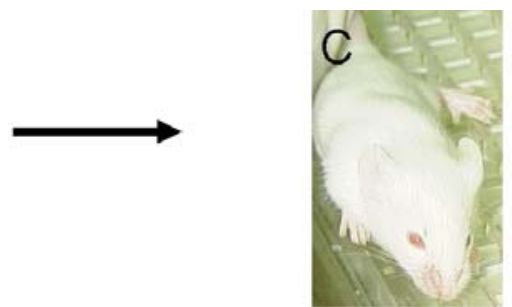

Modified ES cell

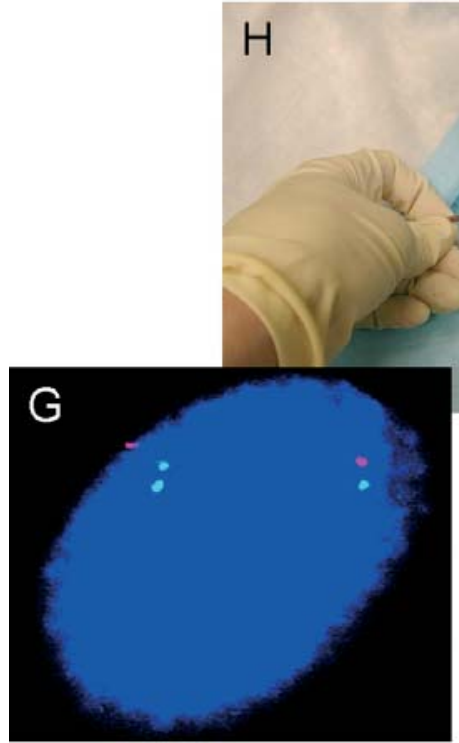

Duplication $(D p 17 /+)$
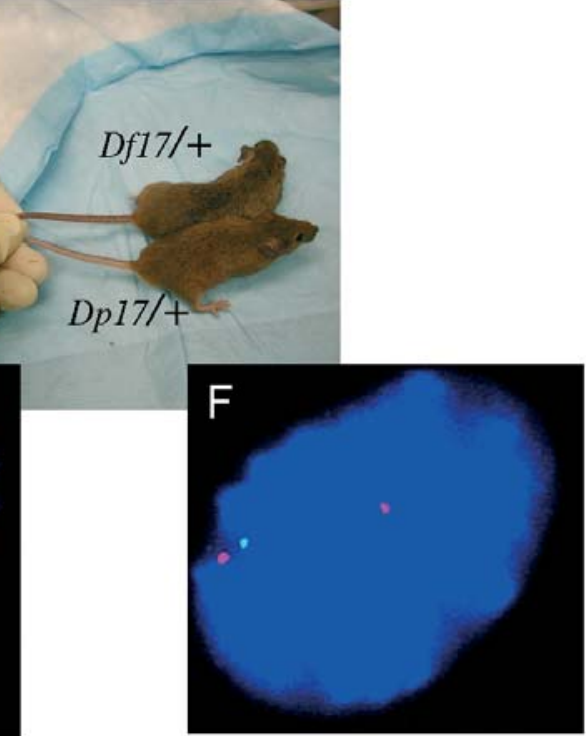

Deletion (Df17/+)

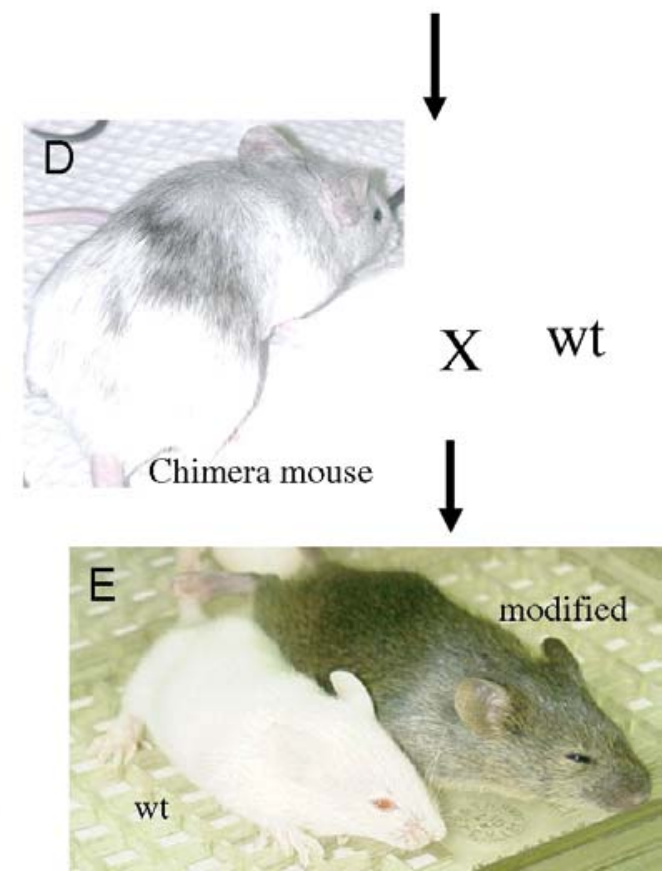

Figure 3 - Schematic representation of the generation of mice carrying genomic rearrangements. ES cells that were first modified with the target of lox $P$ sites and Cre recombinase transient expression in order to obtain the desired rearrangement are analyzed. Mini Southern analysis and FISH (in this example a BAC containing the PMP22 gene that is outside the region to be modified was labeled in red, and a BAC containing the Srebp 1 gene, inside the rearranged region, was labeled with green) (A) are done in order to identify the engineered chromosomes. Once the ES cells carrying the modification are identified they are injected into a wild type embryo in the blastocyst stage (B), and these are implanted in a foster mother (C). Chimeric mice are born, which will have different percentages of chimerism, and are in general recognizable by patches of different coat color. Each chimeric mouse will be mated with a wild type mouse (D); their progeny will include wild type animals and others derived from the initial ES cell (E), some of which will be carrying the modification. In this specific case all the animals derived from the modified ES cell will be modified due to the fact that there were rearrangements in both chromosomes (a deletion in one and the reciprocal duplication in the other). FISH on tail fibroblasts can be used to confirm the genotypes (F-G). Also these specific mice could be distinguished between each other by coat color $(\mathrm{H})$.

34 bp loxP sites) that facilitates the recombination between the two loxP sites, achieving the corresponding genomic rearrangement. The type of chromosome rearrangement obtained will be a direct consequence of the relative initial $\operatorname{lox} P$ configurations. If the $\operatorname{lox} P$ sites are in the same or direct orientation, the region between them will be deleted or duplicated. If the two loxP sites are inverted or in opposite orientation, then the genomic region between them will be inverted (Mills and Bradley, 2001; Yu and Bradley, 2001). Another versatility of this methodology is the possibility to choose the desired endpoints, with the extra advantage of the availability of two complementary libraries (the 5' Hprt library and the 3'Hprt library) for the initial targeting events. About 100,000 clones from these libraries have recently been sequenced and indexed on the mouse genome as a Mutagenic Insertion and Chromosome Engineering Resource (MICER) (Adams et al., 2004). Each of the libraries contain one half of the Hprt cassette in the vector backbone that when reassembled can be selected for in culture due to the resistance to hypoxanthine aminopterin thymidine (HAT) conferred by the reconstructed Hprt gene generated after the Cre mediated recombination. The vector backbones also include coat color markers and selectable markers (Zheng et al., 1999). If the targeted endpoints are in the same chromosome, or in homologous chromosomes, then a deficiency, duplication or an inversion can be obtained; if the endpoints are in different chromosomes, a balanced translocation can be generated.

\section{Mouse Models for Complex Syndromes Due to DNA Rearrangements}

Chromosomal engineering mediated by the Cre-loxP recombination system is particularly useful for modeling large deletions and their reciprocal duplications, as well as inversions. Other techniques have been explored to refine 
the critical region and to identify dosage sensitive gene(s) responsible for different phenotypic features in several CGS deletions (Figure 4). These include the generation of nested chromosomal deletions, targeted mutagenesis and transgenesis. Although extremely informative relative to a potential role for two or more different genes in the etiology of the disease, or position effects as they relate to phenotypic expression, the generation of nested deletions is time-consuming and may not always reproduce the full clinical spectrum of the disease.

Targeted mutagenesis is the most logical approach when there is evidence that a single gene is responsible for the observed clinical features. It has been valuable in the case of genomic disorders wherein it was possible to identify non-deleted patients with the full/partial phenotype associated with point mutations in a specific gene. However, it is possible that a single gene is responsible for the predominant clinical features, while other genes in the critical region convey modifying effects. In this case, a double knock-out may be necessary to completely reproduce the clinical spectrum. Targeted mutagenesis can be combined with nested deletions, if available, or simply be supplemented by transgenesis to elucidate phenotypic effects of different allelic combinations.

Transgenesis has been used extensively to: i) narrow down the critical region in certain CGS, ii) to produce overexpressing animal models that mimic duplication syndromes, and iii) to complement the phenotype (either fully or partially) when a murine model constructed by either targeted mutagenesis or chromosome engineering of the disease is available. This technique is rapid relative to the previous ones described and it is particularly powerful to assess gene dosage effects. Initially, relatively small transgenes integrated in the mouse genome showed low levels of expression, but with the recent availability of large genomic clones ( $\mathrm{YAC} / \mathrm{BAC} / \mathrm{PAC}$ ), transgene expression is usually spatially and temporally correct, since the regula-

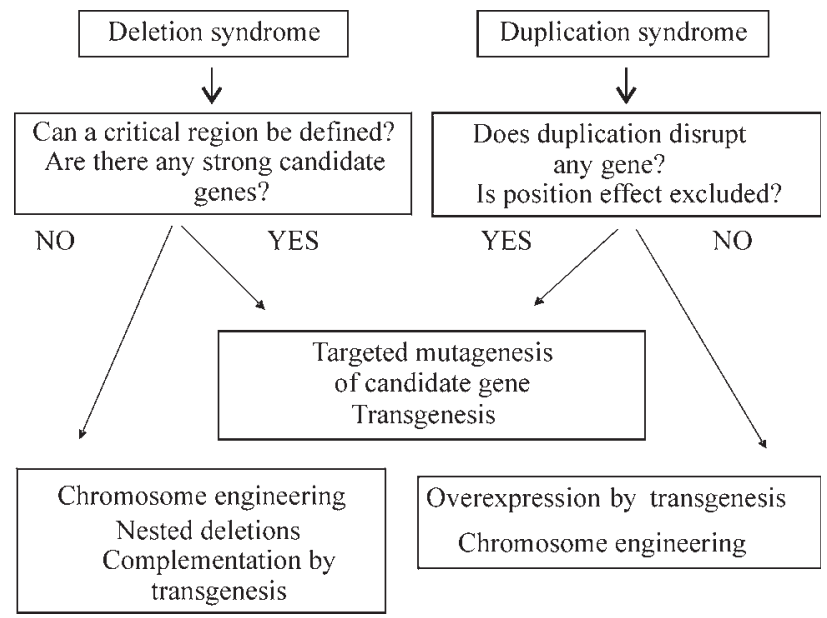

Figure 4 - Schematic representation of the most probable pathways leading to the production of a mouse model for a specific genomic disorder. tory regions crucial for full expression are included. Levels of expression mimic the endogenous gene and correlate with the number of copies integrated in the genome. The copies are usually integrated in tandem at a unique site within the genome, although rearrangements accompanying transgenesis have been described.

When analyzing a complex phenotype in the mouse and attempting to recapitulate a CGS, several factors must be considered that may complicate the assessment of correlation between a specific gene and a specific phenotypic feature. Rearrangements can occur in transgenic mice; the probability of such increases with the size of the fragment integrated. Dosage sensitive genes can be modified by strain background effects, thus different strains must be evaluated. These caveats can add substantial time and expense to the analysis. Nevertheless, these techniques have enabled the development of mouse models for several genomic disorders. Here we discuss selected examples in which insights into the disease process were gleaned from mouse models.

\section{Charcot-Marie-Tooth Disease - Human Hereditary Neuropathy with Liability to Pressure Palsies}

Peripheral myelin protein-22, PMP22, is a major component of myelin expressed in the compact portion of essentially all myelinated fibers in the peripheral nervous system and is produced predominantly by Schwann cells. A duplication on chromosome $17 \mathrm{p} 12$ was identified as the basis of Charcot-Marie-Tooth disease type 1 (CMT1A) (Lupski et al., 1991), whereas an interstitial deletion including the PMP22 gene was observed in patients with $\mathrm{He}-$ reditary Neuropathy with Liability to Pressure Palsies (HNPP) (Chance et al., 1993). These distinct conditions represent prototypical disorders for the elucidation of the mechanism responsible for genomic disorders, as low copy repeats (LCRs) were identified in the region involved and nonallelic homologous recombination (NAHR) using these repeats as recombination substrates results in either the duplication or deletion (Pentao et al., 1992; Chance et al., 1994, Reiter et al., 1996; Reiter et al., 1998).

A mouse model for CMT1A was constructed by pronuclear injection of a YAC containing the human PMP22 gene and a large proportion of the region duplicated in CMT1A (Huxley et al., 1996). This mouse developed a peripheral neuropathy closely resembling that observed in human CMT1A, with progressive weakness of the hind legs, severe demyelination in the peripheral nervous system, and the presence of onion bulb formations on neuropathology. Transgenic lines harboring a much greater Pmp22 copy number (Magyar et al., 1996) revealed complete absence of myelin. A transgenic rat model with increased expression of $P M P 22$ was described by Sereda et al. (1996). PMP22-transgenic rats develop gait abnormali- 
ties caused by a peripheral hypomyelination, Schwann cell hypertrophy (onion bulb formation), muscle weakness and reduced nerve conduction velocities. Homozygous transgenic animals completely fail to elaborate myelin.

To model HNPP, the Pmp22 gene was targeted (Adlkofer et al., 1995). Homozygous null mice develop a neuropathy similar to HNPP with very slow conduction velocities, while heterozygous mice show a less severe phenotype. The generation of a hypomorphic allele of the gene by injection of antisense RNA (Maycox et al., 1997) showed that even with a relatively low decrease in levels of endogenous expression, a phenotype resembling HNPP is observed, though at a somewhat slower rate.

Since it was proposed that impaired Schwann cell differentiation was the mechanism responsible for hereditary peripheral neuropathies, Perea et al. (2001) generated a transgenic mouse model for CMT in which mouse Pmp22 overexpression occurs specifically in Schwann cells of the peripheral nerve and is switched off when the mice are fed tetracycline. When the gene is overexpressed throughout life, demyelination occurs. In contrast, myelination is nearly normal when Pmp 22 overexpression is inactivated. Interestingly, if the gene is switched off in adult mice, abrogation of the demyelination begins within 1 week and myelination is well advanced by 3 months. The observation of correction of the neuropathology suggests that even after the initiation of demyelination, therapeutic intervention may be of substantial benefit, which is encouraging towards a therapy using drugs or gene transfer. In previously normal adult mice, overexpression of Pmp 22 is followed by active demyelination. The authors hypothesized that even adult mice are sensitive to the level of expression of Pmp22 with respect to homeostasis of the myelin sheath (Perea et al., 2001).

The steroid hormone progesterone has been shown to stimulate Pmp22 gene expression both in cultured Schwann cells and in adult mice (Melcangi et al., 1999). Recently, utilizing the rat model of CMT1A with extra copies of the Pmp22 gene (Sereda et al., 1996), male mice that were treated with the progesterone antagonist onapristone showed reduced overexpression of Pmp22 and clinical improvement in the CMT phenotype (as indicated by maintenance of large axons and improved motor performance) (Sereda et al., 2003). Pmp 22 mRNA was decreased by $15 \%$ in onapristone-treated animals, suggesting that even a small reduction in Pmp22 transcription may have a beneficial effect on the disease course (Sereda et al., 2003). The availability of different models expressing different levels of the PMP22 protein (overexpressing transgenic mice, hypomorph, heterozygous and homozygous null) allowed the establishment of a correlation between the severity of the phenotype, assessed by peripheral myelin ultrastructure and nerve conduction, and protein expression. These mouse models confirmed that gene dosage is a critical etiological factor for both CMT1A and HNPP; and provide fan- tastic tools for the exploration of therapeutics for these diseases. It is interesting to speculate that progesterone agonist may be useful in the treatment of HNPP.

\section{DiGeorge Syndrome}

DiGeorge syndrome (DGS) is a genomic disorder caused by a heterozygous deletion of chromosome 22q11. DGS patients present with several phenotypic abnormalities, including cleft palate, cardiovascular defects, thymic hypoplasia, hypothyroidism, and learning disabilities. The triad that defines the syndrome is congenital heart disease characterized by right-sided lesions (most notably interrupted aortic arch), hypocalcemia resulting from parathyroid hypoplasia, and frequent infections due to immunodeficiency secondary to thymic aplasia. Each of these structures (heart, thymus and parathyroid) is derived from the $3^{\text {rd }}$ and $4^{\text {th }}$ pharyngeal pouches.

Several groups attempted the generation of an animal model that recapitulates the syndrome. Lindsay et al. (1999) created an animal model for DGS using Cre-loxP chromosome engineering in ES cells (Ramirez-Solis et al., 1995). They engineered a deletion of a portion of mouse chromosome 16B that is syntenic with human chromosome 22q11 and contains many of the orthologous genes. They reported that $26 \%$ of the 18.5 days postcoitum embryos carrying the heterozygous deletion had cardiovascular abnormalities, and $18 \%$ of adult mice harboring the deletion or deficiency, had cardiovascular abnormalities. However, such mice had normal levels of calcium, phosphorus, and parathyroid hormone, normal percentages of $\mathrm{B}$ and $\mathrm{T}$ cells, and the thymus was normal in size. In addition, none of the mice harboring the deletion had cleft palate or gross palatal abnormalities. Deficiency mice showed abnormalities in sensorimotor gating, learning, and memory (Paylor et al., 2001).

Using a combination of chromosome engineering and $\mathrm{P} 1$ artificial chromosome transgenesis the $T b x \mathrm{l}$ gene, that encodes a member of the T-box transcription factor family that maps to 22q11 in humans, was shown to be required for normal development of the pharyngeal arch arteries in a gene dosage-dependent manner (Lindsay et al., 2001). These observations indicated that haploinsufficiency of Tbxl is sufficient to generate at least one important component of the DGS phenotype in mice. Null mutations of the Tbxl gene were also produced (Jerome and Papaioannou, 2001). Heterozygous $T b x I^{+/}$mice had a high incidence of cardiac outflow tract anomalies, thus modeling one of the major abnormalities of the human syndrome. Mice that were hemizygous for a $1.5-\mathrm{Mb}$ deletion syntenic to that on 22q11 in DGS patients were generated by chromosome engineering using a Cre-loxP strategy (Merscher et al., 2001). These mice exhibited heart conotruncal and parathyroid defects. The conotruncal defects could be partially rescued by a human BAC containing the $T B X 1$ gene again implicating $T B X 1$ as having a major role in the molecular etiology of 
DGS. However, definitive proof that haploinsufficiency of $T B X 1$ is causative for DGS in humans was only recently obtained, when mutations in the $T B X 1$ gene were found in nondeleted patients with features of DGS (Yagi et al., 2003).

The $C R K L$ gene that encodes an SH2-SH3-SH3 adaptor protein maps within the common deletion region for DGS. Mice homozygous for a targeted null mutation at the $\mathrm{Crkl}$ locus exhibit defects in multiple cranial and cardiac neural crest derivatives including the cranial ganglia, aortic arch arteries, cardiac outflow tract, thymus, parathyroid glands, and craniofacial structures. Thus, Crkl may be involved in the molecular mechanism underlying DGS in the case of deletion. Another gene that seems to be involved in the cardiac phenotype is $R A L D H 2$ encoding retinoic acidsynthesizing enzyme. Hypomorphic alleles in mice result in prenatal death of the mutant mice with heart outflow tract septation defects and anomalies of the aortic arch-derived head and neck arteries, laryngeal-tracheal cartilage defects, and thyroid/parathyroid aplasia or hypoplasia (Vermont et al., 2003). These observations are consistent with a decreased level of embryonic retinoic acid (through genetic and/or nutritional causes) potentially representing a major modifier of the expressivity of human 22q11del-associated DGS. Several gene mutations have been found in mice affecting the development of the pharyngeal apparatus (for a recent review see Vitelli and Baldini, 2003). As most of the DGS patients have the same chromosomal deletion, but a great degree of clinical variability, the presence of modifiers is strongly suggested. Further investigations are required to determine if any of these genes play a role in the DGS phenotype.

\section{Prader-Willi / Angelman Syndrome}

Prader Willi syndrome (PWS) and Angelman syndrome (AS) are clinically distinct disorders, and represent important examples of genomic imprinting in humans. Each results from deletion of 15q11-13, paternal deletion or maternal uniparental disomy (UPD) gives PWS whereas maternal deletion or paternal UPD leads to AS. The cardinal features associated with PWS are decreased fetal activity, neonatal hypotonia, obesity and psychomotor and mental retardation. The clinical manifestations of AS include severe cognitive impairment, absence of speech, ataxia, seizures, and inappropriate laughter. Cattanach et al. (1992) described a putative mouse model of PWS, wherein the phenotype was associated with maternal duplication (partial maternal disomy) for the region of mouse chromosome 7 syntenic to human 15q11-q13. The Snrpn gene was not expressed with the maternal duplication. A paternal duplication of the same region (Cattanach et al., 1997) exhibited characteristics of AS, with reduced growth rate during the first 4 to 5 weeks of life, and obesity by 6 months of age, a smaller overall skeletal size, and neurobehavioral differences. Mice with the heterozygous paternal duplication also displayed a mild gait ataxia with slight eversion of the hind limbs and showed marked behavioral hyperactivity relative to their normal sibs in open field testing. Neuropathologic examinations revealed that total brain weight was diminished by about $10 \%$. Electrocorticographic (ECoG) recordings on paternally duplicated mice showed a striking diffuse cortical excitability disturbance that was identical in all animals. However, mice harboring an intragenic deletion in Snrpn are phenotypically normal (Yang et al., 1998) suggesting that mutations of Snrpn are not sufficient to produce the PWS phenotype. Mice with larger deletion, including both Snrpn and the putative PWS-IC (PWS- imprinting center), lack expression of the imprinted genes $Z f p 127, N d n$ and $I p w$, and manifest several phenotypes of PWS patients (Yang et al., 1998).

Mice with the maternal or paternal Ube3A genes knocked out were generated and compared with their wildtype littermates (Jiang et al., 1998). Mice with paternal deficiency $(\mathrm{p}-\mathrm{m}+)$ were essentially similar to wild type mice. Maternal deficiency $\left(\mathrm{m}-/ \mathrm{p}^{+}\right)$mice resemble human AS with motor dysfunction, inducible seizures, and a context-dependent learning deficit. The absence of detectable expression of Ube $3 A$ in hippocampal neurons and Purkinje cells in $\mathrm{m}-\mathrm{p}+$ mice, indicated that imprinting, with silencing of the paternal allele, correlated well with the neurologic and cognitive impairments. Long-term potentiation in the hippocampus was severely impaired. The cytoplasmic abundance of p53 was found to be greatly increased in Purkinje cells and in a subset of hippocampal neurons in $\mathrm{m}-/ \mathrm{p}+$ mice, as well as in a deceased AS patient. Jiang et al., 1998 suggested that failure of Ube $3 A$ to ubiquitinate target proteins and promote their degradation could be a key aspect of the pathogenesis of AS.

\section{Smith-Magenis Syndrome - $\operatorname{dup}(17)(\mathrm{p} 11.2 \mathrm{p} 11.2)$}

Smith-Magenis syndrome (SMS) is a genomic disorder associated with a deletion within sub-band p11.2 of chromosome 17. Recently, mutations in RAII (retinoic acid-induced gene 1) were found in rare patients with many features consistent with SMS and without a recognizable deletion (Slager et al., 2003). The SMS clinical phenotype has been well described and includes craniofacial abnormalities, brachydactyly, self injurious behavior, sleep abnormalities, and mental retardation. Less commonly reported is cleft palate, congenital heart defects, seizures, hearing impairment, and urinary tract anomalies. Patients harboring the predicted reciprocal duplication product, $\operatorname{dup}(17)(\mathrm{p} 11.2 \mathrm{p} 11.2)$, have also been described (Potocki et al., 2000). The phenotype for this independent syndrome associated with the duplication rearrangement seems to be less severe than SMS with mild to borderline mental retardation and behavioral difficulties in the few reported pa- 
tients. Mice carrying a deletion or duplication of the syntenic region on mouse chromosome 11 that spans the genomic interval commonly deleted in SMS patients were constructed, using Cre-loxP chromosome engineering. Heterozygous deleted mice exhibit craniofacial abnormalities, seizures, marked obesity, and male-specific reduced fertility (Walz et al., 2003). Compound heterozygous (i.e., Del/Dup) mice did not display any of these major phenotypes consistent with the trait expression being related to gene dosage effects and not consistent with position effects playing a major role in their manifestation. Behavioral testing of these mice indicates that heterozygous male mice carrying the engineered deletion are hypoactive and show circadian rhythm alterations (Walz et al., 2004).

Heterozygous duplicated animals are underweight and do not have seizures, craniofacial abnormalities, or reduced fertility (Walz et al., 2003). Heterozygous male mice carrying the engineered duplication are hyperactive and they have impaired contextual fear conditioning (Walz et al., 2004). Of interest to note is that the behavioral phenotypes seem to be complementary when comparing the Del versus the Dup mice; hypoactive with deficiency while hyperactive with duplication. Is this caused by a gene dosage effect or are position effects involved? This question will be answered by the analysis of Del/Dup animals in the same battery of behavioral tests. The penetrance of the different phenotypes varies with the genetic background of the mice and deletion size (Yan et al., submitted) Disruption of several genes included in the genomic region containing the common deletion found in SMS patients have been reported, Srebp-1 (Shimano et al., 1997), Pemt (Walkey et al., 1997), Myo15 (Probst et al., 1998), Taci (Yan et al., 2001), Top IIIá (Li et al., 1998) and Fliih (Campbell et al., 2002) and no phenotypes have been described in the heterozygous animals indicating that these genes are not responsible for the phenotypes observed in SMS patients. Csn3, the subunit 3 of the signalosome, deficiency seems not to be responsible for the haploinsufficient phenotypes observed in mice, and homozygous Csn3 -/- results in lethality (Yan et al., 2003).

To clarify the extent to which each gene present in the region contributes to the phenotype observed in SMS, nested deletion encompassing different segments of the initial deletion mouse are being analyzed in our laboratory. Also, individual gene knockouts within the critical region are being developed. Alternatively, BAC transgenesis of candidates genes are being analyzed in order to determine which gene(s) is responsible for the $\operatorname{dup}(17)(\mathrm{p} 11.2 \mathrm{p} 11.2)$ phenotype. Is the same gene(s) involved in the phenotypes expressed with deletion and duplication? Are there multiple genes causing each syndrome? Or different single genes involved? RAI1 seems to be the major player in the SMS phenotype (Slager et al., 2003), but is it responsible for the phenotype present in $\operatorname{dup}(17)(\mathrm{p} 11.2 \mathrm{p} 11.2)$ ? Mouse models that recapitulate two independent human syndromes that result from either decreased (deletion) or increased (duplication) gene dosage involving the identical genomic interval enable a powerful means to investigate the phenotypic consequences of gene dosage imbalance.

\section{Adrenal Hypoplasia Congenita - Sex Reversion}

Adrenal Hypoplasia Congenita (AHC) and the phenotype resulting from the reciprocal duplication, DosageSensitive Sex Reversal (DSS) are examples of conditions caused by an X-linked dosage sensitive gene, $D A X 1$. $D A X 1$ encodes a nuclear hormone receptor that is a negative regulator of retinoic-acid receptor. Deletion and point mutations of $D A X 1$ result in both $\mathrm{AHC}$ and hypogonadotrophic hypogonadism (Muscatelli et al., 1994). When duplicated, $D A X 1$ causes male-to-female sex reversal. Identification of males deleted for the same region suggested that the locus is not required for testis differentiation, but is involved in ovarian development or functions as a link between ovarian and testicular formation (Bardoni et al., 1994). A logical approach to dissect the molecular role of $D A X 1$ gene in mice was to generate a null mutant by targeted mutagenesis (Yu et al., 1998) and an overexpressing transgenic model (Swain et al., 1998), which revealed some surprises.

$\mathrm{XY}$ mice carrying extra copies of the transgene show delayed testis development but no sex reversal. The sex reversal phenotype occurs only when crosses are made with mice harboring weak alleles of the sex-determining $\mathrm{Y}$ chromosome gene $(S r y)$. Therefore, the authors hypothesized that Daxl acts as an anti-testis gene by antagonizing Sry action and that the transgenic mouse model indicates that the dosage-sensitive sex reversal observed in humans is caused by the duplication of the gene. On the other hand, the disruption of the gene showed decreased testicular size and progressive degeneration of the germinal epithelium, however not as a consequence of the hormonal dysfunction. Females had neither development nor fertility affected. Attempts to rescue the phenotype with a Dax 1 transgene were only partially successful. Jeffs et al., (2001) and Meeks et al., (2003) generated tissue-specific Daxl transgenic mice that were crossed with the deficient model. The partial recovery from infertility and testicular pathology suggests that the receptor has a functional role in different gonadal cell types.

\section{Wolf-Hirschhorn Syndrome}

Wolf-Hirschhorn syndrome (WHS) is a terminal deletion syndrome caused by segmental haploidy of chromosome 4p16.3. The phenotypic presentation includes a "Greek warrior helmet" facial appearance (prominent glabella, hypertelorism, widely set eyes), various midline closure defects, growth retardation, juvenile seizures, cataracts, iris colobomas, and mental retardation (Lurie et al., 1980; Wilson et al., 1981). Utilizing nested deletions generated by ES cell irradiation (You et al., 1997), five mouse 
models with different sized deletions in the mouse chromosome 5 (in a region of conserved synteny with human 4 p16.3) were produced (Naf et al., 2001). Several phenotypes present in the patients were recapitulated in these animals. These included: growth retardation, susceptibility to seizures, and midline (palate closure, tail kinks), craniofacial, and ocular anomalies (coloboma, corneal opacities). Other phenotypes included cerebellar hypoplasia and a shortened cerebral cortex. Expression of WHS-like traits was variable and influenced by strain background and deletion size.

\section{Conclusion}

Genomic disorders refer to a group of syndromes caused by DNA rearrangements, such as deletions and duplications, which result in an alteration of normal gene dosage within a defined genomic interval. Altered dosage of a single gene (e.g. CMT1A and HNPP), or potentially several genes, that are included in the rearranged region is responsible for the phenotype. The chromosomal rearrangements involved in genomic disorders are the result of NAHR utilizing flanking LCRs as recombination substrates. Generally speaking, phenotypes that result from dosage effects may display significant variability. Some variation may reflect modifying effects from i) genetic background, ii) deletion/duplication of other genes in rearranged segment, and/or iii) alterations in allelic gene expression from the nonrearranged allele.

The human and mouse genome sequencing projects are complete. This tremendous genomic information in conjunction with the ability to engineer mouse chromosome rearrangements have enabled the construction of mouse models for CGS and other genomic disorders paving the way to determine the roles of specific genes, allelic interactions, position effects and potential modifier genes in the ultimate phenotypic expression. Single gene manipulations in mice have been ongoing for greater than a decade and many mouse models have been constructed. However, until recently the idea of mouse models for rearrangement based genomic disorders were technically extremely challenging. Fortunately, with the appearance of techniques allowing chromosomal engineering systematic studies to investigate rearrangements and gene dosage effects are being implemented. Moreover, as presented here, in several mouse models for genomic disorders, specific phenotypes present in human patients have been recapitulated in the engineered mice, including learning disabilities and behavioral phenotypes.

An important example of the value of mouse genetics for understanding human disease was shown for DGS. After several attempts to find the gene responsible for this syndrome (Lindsay et al., 1999; Gong et al., 2001), and having a clear clue that $T b x 1$ was responsible for part of the phenotypes in mice, human patients having the clinical phenotype of DGS, but not a distinguishable deletion were found to harbor mutations in TBX1 (Yagi et al., 2003).

Another advantage of having animal models for these syndromes is clearly the possibility of treating some of the symptoms. We reviewed the improvement seen in a rat model for CMT1A when treated with a progesterone antagonist. Correct dosage of selected genes may be crucial for normal development. The possibility of having different size rearrangements, point mutations, duplications, and transgenic animals will enable systematic investigation to identify dosage sensitive genes and how altered levels of expression can affect phenotypes.

\section{Acknowledgements}

We appreciate the critical reviews of Drs W. Bi, J. Yan, P. Stankiewicz and L. Pentao. This work has been supported in part by the National Cancer Institute, NIH (PO1CA75719).

\section{References}

Adams DJ, Bigg PJ, Cox T, Davies R, van der Weyden L, Jonkers J, Smith J, Plumb B, Taylor R, Nishijima F, Yu Y, Rogers J and Bradley A (2004) Mutagenic Insertion and Chromosome Engineering Resource (MICER). Nat Genet, published online: 04 July, 2004. doi: 10.1038/ng1388.

Adlkofer K, Martini R, Aguzzi A, Zielasek J, Toyka KV and Suter U (1995) Hypermyelination and demyelinating peripheral neuropathy in Pmp22-deficient mice. Nat Genet 11:274280.

Ahmad A, Brinson M, Hodges BL, Chamberlain JS and Amalfitano A (2000) $M d x$ mice inducibly expressing dystrophin provide insights into the potential of gene therapy for Duchenne muscular dystrophy. Hum Mol Genet 9:2507-2515.

Ashery-Padan R, Marquardt T, Zhou X and Gruss P (2000) Pax6 activity in the lens primordium is required for lens formation and for correct placement of a single retina in the eye. Genes Dev 14:2701-2711.

Bardoni B, Zanaria E, Guioli S, Floridia G, Worley KC, Tonini G, Ferrante E, Chiumello G, McCabe ER, Fraccaro M, Zuffardi O and Camerino G (1994) A dosage sensitive locus at chromosome Xp21 is involved in male to female sex reversal. Nat Genet 7:497-501.

Berk M, Desai SY, Heyman HC and Colmenares C (1997) Mice lacking the ski proto-oncogene have defects in neurulation, craniofacial patterning and skeletal muscle development. Genes Dev 11:2029-2039.

Brannan CI, Perkins AS, Vogel KS, Ratner N, Nordlund ML, Reid SW, Buchberg AM, Jenkins NA, Parada LF and Copeland NG (1994) Targeted disruption of the neurofibromatosis type-1 gene leads to developmental abnormalities in heart and various neural crest-derived tissues. Genes Dev 8:1019-1029.

Cahana A, Escamez T, Nowakowski RS, Hayes NL, Giacobini M, von Holst A, Shmueli O, Sapir T, McConnell SK, Wurst W, Martinez S and Reiner O (2001) Targeted mutagenesis of Lis1 disrupts cortical development and LIS1 homodimerization. Proc Nac Acad Sci USA 98:6429-6434. 
Campbell HD, Fountain S, McLennan IS, Berven LA, Crouch MF, Davy DA, Hooper JA, Waterford K, Chen K-S, Lupski JR, Ledermann B, Young IG and Matthaei KI (2002) Fliih, a gelsolin-related cytoskeletal regulator essential for early mammalian embryonic development. Mol Cell Biol 22:3518-3526.

Caspary T, Cleary MA, Perlman EJ, Zhang P, Elledge SJ and Tilghman SM (1999) Oppositely imprinted genes p57(Kip2) and $\operatorname{Ig} f 2$ interact in a mouse model for BeckwithWiedemann syndrome. Genes Dev 13:3115-3124.

Cattanach BM, Barr JA, Beechey CV, Martin J, Noebels J and Jones J (1997) A candidate model for Angelman syndrome in the mouse. Mamm Genome 8:472-478.

Cattanach BM, Barr JA, Evans EP, Burtenshaw M, Beechey CV, Leff SE, Brannan CI, Copeland NG, Jenkins NA and Jones J (1992) A candidate mouse model for Prader-Willi syndrome which shows an absence of Snrpn expression. Nat Genet 2:270-274.

Chance PF, Abbas N, Lensch MW, Pentao L, Roa BB, Patel PI and Lupski JR (1994) Two autosomal dominant neuropathies result from reciprocal DNA duplication/deletion of a region on chromosome 17. Hum Mol Genet 3:223228.

Chance PF, Alderson MK, Leppig KA, Lensch MW, Matsunami N, Smith B, Swanson PD, Odelberg SJ, Disteche CM and Bird TD (1993) DNA deletion associated with hereditary neuropathy with liability to pressure palsies. Cell 72:143151.

Charalambous M, Smith FM, Bennett WR, Crew TE, Mackenzie F and Ward A (2003) Disruption of the imprinted Grb10 gene leads to disproportionate overgrowth by an $I g f 2$-independent mechanism. Proc Nac Acad Sci USA 100:82928297.

Chen ZF and Behringer RR (1995) Twist is required in head mesenchyme for cranial neural tube morphogenesis. Genes Dev 9:686-699.

Chiang C, Litingtung Y, Lee E, Young KE, Corden JL, Westphal $\mathrm{H}$ and Beachy PA (1996) Cyclopia and defective axial patterning in mice lacking Sonic hedgehog gene function. Nature 383:407-413.

Cox GA, Cole NM, Matsumura K, Phelps SF, Hauschka SD, Campbell KP, Faulkner JA and Chamberlain JS (1993) Overexpression of dystrophin in transgenic $m d x$ mice eliminates dystrophic symptoms without toxicity. Nature 364:725-729.

Dautigny A, Mattei MG, Morello D, Alliel PM, Pham-Dinh D, Amar L, Arnaud D, Simon D, Mattei JF, Guenet JL, Jollès P and Avner P (1986) The structural gene coding for myelin-associated proteolipid protein is mutated in jimpy mice. Nature 321:867-869.

Emanuel BS and Shaikh TH (2001) Segmental duplications: An 'expanding' role in genomic instability and disease. Nat Rev Genet 2:791-800.

Elms P, Siggers P, Napper D, Greenfield A and Arkell R (2003) $Z i c 2$ is required for neural crest formation and hindbrain patterning during mouse development. Dev Biol 264:391-406.

Funke B, Epstein JA, Kochilas LK, Lu MM, Pandita RK, Liao J, Bauerndistel R, Schuler T, Schorle H, Brown MC, Adams J and Morrow BE (2001) Mice overexpressing genes from the $22 \mathrm{q} 11$ region deleted in velo-cardio-facial syn-
drome/DiGeorge syndrome have middle and inner ear defects. Hum Molec Genet 10:2549-2556.

Gabriel JM, Merchant M, Ohta T, Ji Y, Caldwell RG, Ramsey MJ, Tucker JD, Longnecker R and Nicholls RD (1999) A transgene insertion creating a heritable chromosome deletion mouse model of Prader-Willi and Angelman syndromes. Proc Nat Acad Sci USA 96:9258-9263.

Gitler AD, Zhu Y, Ismat FA, Lu MM, Yamauchi Y, Parada LF and Epstein JA (2003) Nf1 has an essential role in endothelial cells. Nat Genet 33:75-79.

Glaser T, Lane J and Housman D (1990) A mouse model of the aniridia-Wilms tumor deletion syndrome. Science 250:823-827.

Goodrich LV, Milenkovic L, Higgins KM and Scott MP (1997) Altered neural cell fates and medulloblastoma in mouse patched mutants. Science 277:1109-1113.

Gong W, Gottlieb S, Collins J, Blescia A, Dietz H, Goldmuntz E, McDonald-McGinn DM, Zackai EH, Emanuel BS, Driscoll DA and Budarf ML (2001) Mutation analysis of TBX1 in non-deleted patients with features of DGS/VCFS or isolated cardiovascular defects. J Med Genet 38:e45.

Guo J-K, Menke AL, Gubler M-C, Clarke AR, Harrison D, Hammes A, Hastie ND and Schedl A (2002) WT1 is a key regulator of podocyte function: Reduced expression levels cause crescentic glomerulonephritis and mesangial sclerosis. Hum Mol Genet 11:651-659.

Guris DL, Fantes J, Tara D, Druker BJ and Imamoto A (2001) Mice lacking the homologue of the human 22q11.2 gene CRKL phenocopy neurocristopathies of DiGeorge syndrome. Nat Genet 27:293-298.

Hatada I, Ohashi H, Fukushima Y, Kaneko Y, Inoue M, Komoto Y, Okada A, Ohishi S, Nabetani A, Morisaki H, Nakayama M, Niikawa M and Mukai T (1996) An imprinted gene p57(KIP2) is mutated in Beckwith-Wiedemann syndrome. Nat Genet 14:171-173.

Hill RE, Favor J, Hogan BL, Ton CC, Saunders GF, Hanson IM, Prosser J, Jordan T, Hastie ND and van Heyningen V (1991) Mouse Small eye results from mutations in a paired-like homeobox-containing gene. Nature 354:522-525.

Hirotsune S, Fleck MW, Gambello MJ, Bix GJ, Chen A, Clark GD, Ledbetter DH, McBain CJ and Wynshaw-Boris A (1998) Graded reduction of Pafahlb1 (Lis 1) activity results in neuronal migration defects and early embryonic lethality. Nat Genet 19:333-339.

Hoogenraad CC, Koekkoek B, Akhmanova A, Krugers H, Dortland B, Miedema M, van Alphen A, Kistler WM, Jaegle M, Koutsourakis M, Van Camp N, Verhoye M, van der Linden A, Kaverina I, Grosveld F, De Zeeuw CI and Galjart N (2002) Targeted mutation of Cyln2 in the Williams syndrome critical region links CLIP-115 haploinsufficiency to neurodevelopmental abnormalities in mice. Nat Genet 32:116-127.

Hui CC and Joyner AL (1993) A mouse model of Greig cephalopolysyndactyly syndrome: The extra-toes $(\mathrm{J})$ mutation contains an intragenic deletion of the Gli3 gene. Nat Genet 3:241-245.

Huq AHM, Lovell RS, Ou C-N, Beaudet AL and Craigen WJ (1997) X-linked glycerol kinase deficiency in the mouse leads to growth retardation, altered fat metabolism, autonomous glucocorticoid secretion and neonatal death. Hum Mol Genet 6:1803-1809. 
Huxley C, Passage E, Manson A, Putzu G, Figarella-Branger D, Pellissier JF and Fontes M (1996) Construction of a mouse model of Charcot-Marie-Tooth disease type 1A by pronuclear injection of human YAC DNA. Hum Mol Genet 5:563-569.

Incerti B, Cortese K, Pizzigoni A, Surace EM, Varani S, Coppola M, Jeffery G, Seeliger M, Jaissle G, Bennett DC, Marigo V, Schiaffino MV, Tacchetti C and Ballabio A (2000) Oal knock-out: New insights on the pathogenesis of ocular albinism type 1. Hum Mol Genet 9:2781-2788.

Inoue K and Lupski JR (2002) Molecular Mechanisms for Genomic Disorders. Annu Rev Genomics Hum Genet 3:199-242.

Inoue Y, Kagawa T, Matsumura Y, Ikenaka K and Mikoshiba K (1996) Cell death of oligodendrocytes or demyelination induced by overexpression of proteolipid protein depending on expressed gene dosage. Neurosci Res 25:161-172.

Jacks T, Shih TS, Schmitt EM, Bronson RT, Bernards A and Weinberg RA (1994) Tumour predisposition in mice heterozygous for a targeted mutation in Nf1. Nat Genet 7:353-361.

Jeffs B, Ito M, Yu RN, Martinson FA, Wang ZJ, Doglio LT and Jameson JL (2001) Sertoli cell-specific rescue of fertility, but not testicular pathology in Daxl (Ahch)-deficient male mice. Endocrinology 142:2481-2488.

Jerome LA and Papaioannou VE (2001) DiGeorge syndrome phenotype in mice mutant for the T-box gene, Tbx 1 . Nat Genet 27:286-291.

Jiang YH, Armstrong D, Albrecht U, Atkins CM, Noebels JL, Eichele G, Sweatt JD and Beaudet AL (1998) Mutation of the Angelman ubiquitin ligase in mice causes increased cytoplasmic p53 and deficits of contextual learning and long-term potentiation. Neuron 21:799-811.

Kishino T, Lalande M and Wagstaff J (1997) UBE3A/E6-AP mutations cause Angelman syndrome. Nat Genet 15:70-73.

Kleymenova E, Ibraghimov-Beskrovnaya O, Kugoh H, Everitt J, $\mathrm{Xu}$ H, Kiguchi K, Landes G, Harris P and Walker C (2001) Tuberin-dependent membrane localization of polycystin-1: A functional link between polycystic kidney disease and the TSC2 tumor suppressor gene. Mol Cell 7:823-832.

Klugmann M, Schwab MH, Puhlhofer A, Schneider A, Zimmermann F, Griffiths IR and Nave KA (1997) Assembly of CNS myelin in the absence of proteolipid protein. Neuron 18:5970.

Kreidberg JA, Sariola H, Loring JM, Maeda M, Pelletier J, Housman D and Jaenisch R (1993) WT-1 is required for early kidney development. Cell 74:679-691.

Kurotaki N, Imaizumi K, Harada N, Masuno M, Kondoh T, Nagai T, Ohashi H, Naritomi K, Tsukahara M, Makita Y, Sugimoto T, Sonoda T, Hasegawa T, Chinen Y, Tomita Ha HA, Kinoshita A, Mizuguchi T, Yoshiura Ki K, Ohta T, Kishino T, Fukushima Y, Niikawa N and Matsumoto N (2002) Haploinsufficiency of NSD1 causes Sotos syndrome. Nat Genet 30:365-366.

Lagutin OV, Zhu CC, Kobayashi D, Topczewski J, Shimamura K, Puelles L, Russell HR, McKinnon PJ, Solnica-Krezel L and Oliver G (2003) Six3 repression of Wnt signaling in the anterior neuroectoderm is essential for vertebrate forebrain development. Genes Dev 17:368-379.

Lee EY-HP, Chang C-Y, Hu N, Wang Y-C J, Lai C-C, Herrup K, Lee W-H and Bradley A (1992) Mice deficient for Rb are nonviable and show defects in neurogenesis and haematopoiesis. Nature 359:288-294.

Li DY, Faury G, Taylor DG, Davis EC, Boyle WA, Mecham RP, Stenzel P, Boak B and Keating MT (1998) Novel arterial pathology in mice and humans hemizygous for elastin. J Clin Invest 102:1783-1787.

Li L, Krantz ID, Deng Y, Genin A, Banta AB, Collins CC, Qi M, Trask BJ, Kuo WL, Cochran J, Costa T, Pierpont ME, Rand EB, Piccoli DA, Hood L and Spinner NB (1997) Alagille syndrome is caused by mutations in human Jagged1, which encodes a ligand for Notch1. Nat Genet 16:243-251.

Li W and Wang JC (1998) Mammalian DNA topoisomerase III $\alpha$ is essential in early embryogenesis. Proc Nat Acad Sci USA 95:1010-1013.

Lin X, Wei G, Shi Z, Dryer L, Esko JD, Wells DE and Matzuk MM (2000) Disruption of gastrulation and heparan sulfate biosynthesis in EXT1-deficient mice. Dev Biol 224:299311.

Lindsay EA, Botta A, Jurecic V, Carattini-Rivera S, Cheah YC, Rosenblatt HM, Bradley A and Baldini A (1999) Congenital heart disease in mice deficient for the DiGeorge syndrome region. Nature 401:379-383.

Lindsay EA, Vitelli F, Su H, Morishima M, Huynh T, Pramparo T, Jurecic V, Ogunrinu G, Sutherland HF, Scambler PJ, Bradley A and Baldini A (2001) Tbxl haploinsufficieny in the DiGeorge syndrome region causes aortic arch defects in mice. Nature 410:97-101.

Lu W, Peissel B, Babakhanlou H, Pavlova A, Geng L, Fan X, Larson C, Brent G and Zhou J (1997) Perinatal lethality with kidney and pancreas defects in mice with a targeted $P k d 1$ mutation. Nat Genet 17:179-181.

Lupski JR, de Oca-Luna RM, Slaugenhaupt S, Pentao L, Guzzetta V, Trask BJ, Saucedo-Cardenas O, Barker DF, Killian JM, Garcia CA, Chakravarti A and Patel PI (1991) DNA duplication associated with Charcot-Marie-Tooth disease type 1A. Cell 66:219-232.

Lupski JR (1998) Genomic disorders: Structural features of the genome can lead to DNA rearrangements and human disease traits. Trends in Genet 14:417-422.

Lupski JR (2003) 2002 Curt Stern Award Address. Genomic disorders recombination-based disease resulting from genomic architecture. Am J Hum Genet 72:246-252.

Lurie IW, Lazjuk GI, Ussova YI, Presman EB and Gurevich DB (1980) The Wolf-Hirschhorn syndrome. I. Genetics. Clin Genet 17:375-384.

Magyar JP, Martini R, Ruelicke T, Aguzzi A, Adlkofer K, Dembic Z, Zielasek J, Toyka KV and Suter U (1996) Impaired differentiation of schwann cells in transgenic mice with increased PMP22 gene dosage. J Neurosci 16:53515360 .

Malik TH, von Stechow D, Bronson RT and Shivdasani RA (2002) Deletion of the GATA domain of TRPS1 causes an absence of facial hair and provides new insights into the bone disorder in inherited tricho-rhino-phalangeal syndromes. Mol Cell Biol 22:8592-8600.

Matsuo T, Osumi-Yamashita N, Noji S, Ohuchi H, Koyama E, Myokai F, Matsuo N, Taniguchi S, Doi H, Iseki S, Ninomiya Y, Fujiwara M, Watanabe T and Eto K (1993) A mutation in the Pax6 gene in rat small eye is associated with impaired migration of midbrain crest cells. Nat Genet 3:299-304. 
Maycox PR, Ortuño D, Burrola P, Kuhn R, Bieri PL, Arrezo JC and Lemke G (1997) A transgenic Mouse Model for Human Hereditary Neuropathy with Liability to Pressure Palsies. Mol Cell Neuroscience 8:405-416.

McCright B, Lozier J and Gridley T (2002) A mouse model of Alagille syndrome: Notch2 as a genetic modifier of Jag1 haploinsufficiency. Development 129:1075-1082.

Meeks JJ, Russell TA, Jeffs B, Huhtaniemi I, Weiss J and Jameson JL (2003) Leydig Cell-Specific Expression of DAX1 Improves Fertility of the Daxl-Deficient Mouse. Biol Reprod 69:154-160.

Melcangi RC, Magnaghi V, Cavarretta I, Zucchi I, Bovolin P, D'Urso D and Martini L (1999) Progesterone derivatives are able to influence peripheral myelin protein 22 and $\mathrm{P}_{0}$ gene expression: Possible mechanisms of action. J Neurosci Res 56:349-357.

Meng Y, Zhang Y, Tregoubov V, Janus C, Cruz L, Jackson M, Lu WY, MacDonald JF, Wang JY, Falls DL and Jia Z (2002) Abnormal spine morphology and enhanced LTP in LIMK-1 knockout mice. Neuron 35:121-133.

Merscher S, Funke B, Epstein JA, Heyer J, Puech A, Lu MM, Xavier RJ, Demay MB, Russell RG, Factor S, Tokooya K, St. Jore B, Jore BS, Lopez M, Pandita RK, Lia M, Carrion D, $\mathrm{Xu} \mathrm{H}$, Schorle H, Kobler JB, Scambler P, Wynshaw-Boris A, Skoultchi AI, Morrow BE and Kucherlapati R (2001) TBX1 is responsible for cardiovascular defects in velocardio-facial/DiGeorge syndrome. Cell 104:619-629.

Mills AA and Bradley A (2001) From mouse to man: Generating megabase chromosome rearrangements. Trends in Genetics 17:331-339.

Muscatelli F, Abrous DN, Massacrier A, Boccaccio I, Le Moal M, Cau P and Cremer H (2000) Disruption of the mouse Necdin gene results in hypothalamic and behavioral alterations reminiscent of the human Prader-Willi syndrome. Hum Mol Genet 9:3101-3110.

Muscatelli F, Strom TM, Walker AP, Zanaria E, Recan D, Meindl A, Bardoni B, Guioli S, Zehetner G, Rabl W, Schwarz HP, Kaplan JC, Camerino G, Meitinger T and Monaco AP (1994) Mutations in the $D A X-1$ gene give rise to both $\mathrm{X}$ linked adrenal hypoplasia congenita and hypogonadotropic hypogonadism. Nature 372:672-676.

Naf D, Wilson LA, Bergstrom RA, Smith RS, Goodwin NC, Verkerk A, van Ommen GJ, Ackerman SL, Frankel WN and Schimenti JC (2001) Mouse models for the WolfHirschhorn deletion syndrome. Hum Mol Genet 10:91-98.

Nave KA, Lai C, Bloom FE and Milner RJ (1986) Jimpy mutant mouse: A 74-base deletion in the mRNA for myelin proteolipid protein and evidence for a primary defect in RNA splicing. Proc Nat Acad Sci USA 83:9264-9268.

Oda T, Elkahloun AG, Pike BL, Okajima K, Krantz ID, Genin A, Piccoli DA, Meltzer PS, Spinner NB, Collins FS and Chandrasekharappa SC (1997) Mutations in the human Jagged1 gene are responsible for Alagille syndrome. Nat Genet 16:235-242.

Oike Y, Hata A, Mamiya T, Kaname T, Noda Y, Suzuki M, Yasue H, Nabeshima T, Araki K and Yamamura K (1999) Truncated CBP protein leads to classical Rubinstein-Taybi syndrome phenotypes in mice: Implications for a dominant-negative mechanism. Hum Mol Genet 8:387-396.

Paylor R, McIlwain KL, McAninch R, Nellis A, Yuva-Paylor LA, Baldini A and Lindsay EA (2001) Mice deleted for the
DiGeorge/velocardiofacial syndrome region show abnormal sensorimotor gating and learning and memory impairments. Hum Mol Genet 10:2645-2650.

Pentao L, Wise CA, Chinault AC, Patel PI and Lupski JR (1992) Charcot-Marie-Tooth type 1A duplication appears to arise from recombination at repeat sequences flanking the $1.5 \mathrm{Mb}$ monomer unit. Nat Genet 2:292-300.

Perea J, Robertson A, Tolmachova T, Muddle J, King RH, Ponsford S, Thomas PK and Huxley C (2001) Induced myelination and demyelination in a conditional mouse model of Charcot-Marie-Tooth disease type 1A. Hum Mol Genet 10:1007-1018.

Petrif F, Giles RH, Dauwerse HG, Saris JJ, Hennekam RC, Masuno M, Tommerup N, van Ommen GJ, Goodman RH, Peters DJ and Breuning MH (1995) Rubinstein-Taybi syndrome caused by mutations in the transcriptional coactivator CBP. Nature 376:348-351.

Phelps SF, Hauser MA, Cole NM, Rafael JA, Hinkle RT, Faulkner JA and Chamberlain JS (1995) Expression of full-length and truncated dystrophin mini-genes in transgenic $m d x$ mice. Hum Mol Genet 4:1251-1258.

Prakash SK, Cormier TA, McCall AE, Garcia JJ, Sierra R, Haupt B, Zoghbi HY and Van den Veyver IB (2002) Loss of holocytochrome $c$-type synthetase causes the male lethality of X-linked dominant microphthalmia with linear skin defects (MLS) syndrome. Hum Mol Genet 11:3237-3248.

Probst FJ, Fridell RA, Raphael Y, Saunders TL, Wang A, Liang Y, Morell RJ, Touchman JW, Lyons RH, Noben-Trauth K, Friedman TB and Camper SA (1998) Correction of deafness in shaker-2 mice by an unconventional myosin in a BAC transgene. Science 280:1444-1447.

Potocki L, Chen KS, Park SS, Osterholm DE, Withers MA, Kimonis V, Summers AM, Meschino WS, Anyane-Yeboa K, Kashork CD, Shaffer LG and Lupski JR (2000) Molecular mechanism for duplication $17 \mathrm{p} 11.2$ - the homologous recombination reciprocal of the Smith-Magenis microdeletion. Nat Genet 24:84-87.

Qu S, Niswender KD, Ji Q, van der Meer R, Keeney D, Magnuson MA and Wisdom R (1997) Polydactyly and ectopic ZPA formation in Alx-4 mutant mice. Development 124:39994008.

Rafael JA, Cox GA, Corrado K, Jung D, Campbell KP and Chamberlain JS (1996) Forced expression of dystrophin deletion constructs reveals structure-function correlations. J Cell Biol 134:93-102.

Ramirez-Solis R, Liu P and Bradley A (1995) Chromosome engineering in mice. Nature 378:720-724.

Rayasam GV, Wendling O, Angrand P-O, Mark M, Niederreither $\mathrm{K}$, Song L, Lerouge T, Hager GL, Chambon P and Losson R (2003) NSD1 is essential for early post-implantation development and has a catalytically active SET domain. EMBO J 22:3153-3163.

Readhead C, Schneider A, Griffiths I and Nave KA (1994) Premature arrest of myelin formation in transgenic mice with increased proteolipid protein gene dosage. Neuron 12:583-595

Reiter LT, Hastings PJ, Nelis E, De Jonghe P, Van Broeckhoven C and Lupski JR (1998) Human meiotic recombination products revealed by sequencing a hotspot for homologous strand exchange in multiple HNPP deletion patients. Am J Hum Genet 62:1023-1033. 
Reiter LT, Murakami T, Koeuth T, Pentao L, Muzny DM, Gibbs RA and Lupski JR (1996) A recombination hotspot responsible for two inherited peripheral neuropathies is located near a mariner transposon-like element. Nat Genet 12:288-297.

Rinchik EM, Flaherty L and Russell LB (1993) High-frequency induction of chromosomal rearrangements in mouse germ cells by the chemotherapeutic agent chlorambucil. Bioessays 15:831-836.

Ruggiu M, Speed R, Taggart M, McKay SJ, Kilanowski F, Saunders P, Dorin J and Cooke HJ (1997) The mouse Dazla gene encodes a cytoplasmic protein essential for gametogenesis. Nature 389:73-77.

Russell, WL (1951) X-ray induced mutations in mice. Cold Spring Harbor Symp Quant Biol 16:327-336.

Saxton TM, Henkemeyer M, Gasca S, Shen R, Rossi DJ, Shalaby F, Feng G-S and Pawson T (1997) Abnormal mesoderm patterning in mouse embryos mutant for the $\mathrm{SH} 2$ tyrosine phosphatase Shp-2. EMBO J. 16:2352-2364.

Schedl A, Ross A, Lee M, Engelkamp D, Rashbass P, van Heyningen $\mathrm{V}$ and Hastie ND (1996) Influence of PAX6 gene dosage on development: Overexpression causes severe eye abnormalities. Cell 86:71-82.

Schmickel RD (1986) Contiguous gene syndromes: A component of recognizable syndromes. J Pediatr 109:231-241.

Sereda M, Griffiths I, Puhlhofer A, Stewart H, Rossner MJ, Zimmermann F, Magyar JP, Schneider A, Hund E, Meinck H-M, Suter U and Nave K-A (1996) A transgenic rat model of Charcot-Marie-Tooth disease. Neuron 16:1049-1060.

Sereda MW, Meyer zu Horste G, Suter U, Uzma N and Nave K-A (2003) Therapeutic administration of progesterone antagonist in a model of Charcot-Marie-Tooth disease (CMT-1A). Nat Med 9:1533-1537.

Shaffer LG and Lupski JR (2000) Molecular mechanisms for constitutional chromosomal rearrangements in humans. Annu Rev Genet 34:297-329.

Shaffer LG, Ledbetter DH and Lupski JR (2001) Molecular Cytogenetics of Contiguous Gene Syndromes: Mechanisms and Consequences of Gene Dosage Imbalance. The Metabolic and Molecular Bases of Inherited Disease. $8^{\text {th }}$ edition. v. I. The McGraw-Hill Companies, Inc., pp 1291-1327.

Shaw CJ and Lupski JR (2004) Implications of human genome architecture for rearrangement-based disorders: The genomic basis of disease. Hum Mol Genet 13 Suppl 1:R57-R64.

Shimano H, Shimomura I, Hammer RE, Herz J, Goldstein JL, Brown MS and Horton JD (1997) Elevated levels of SREBP-2 and cholesterol synthesis in livers of mice homozygous for a targeted disruption of the SREBP-1 gene. J Clin Invest 100:2115-2124.

Sicinski P, Geng Y, Ryder-Cook AS, Barnard EA, Darlison MG and Barnard PJ (1989) The molecular basis of muscular dystrophy in the $m d x$ mouse: A point mutation. Science 244:1578-1580.

Sidman RL, Dickie MM and Appel SH (1964) Mutant mice (quaking and jimpy) with deficient myelination in the central nervous system. Science 144:309-311.

Slager RE, Newton TL, Vlangos CN, Finucane B and Elsea SH (2003) Mutations in RAI1 associated with Smith-Magenis syndrome. Nat Genet 33:466-468.

Slee R, Grimes B, Speed RM, Taggart M, Maguire SM, Ross A, McGill NI, Saunders PT and Cooke HJ (1999) A human
$D A Z$ transgene confers partial rescue of the mouse Dazl null phenotype. Proc Nat Acad Sci USA 96:8040-8045.

Stankiewicz P and Lupski JR (2002) Genome architecture, rearrangements and genomic disorders. Trends in Genet 18:7482.

Suter U, Welcher AA, Ozcelik T, Snipes GJ, Kosaras B, Francke U, Billings-Gagliardi S, Sidman RL and Shooter EM (1992) Trembler mouse carries a point mutation in a myelin gene. Nature 356:241-244.

Swain A, Narvaez V, Burgoyne P, Camerino G and Lovell-Badge R (1998) Daxl antagonizes Sry action in mammalian sex determination. Nature 391:761-767.

Tanaka Y, Naruse I, Maekawa T, Masuya H, Shiroishi T and Ishii S (1997) Abnormal skeletal patterning in embryos lacking a single $C b p$ allele: A partial similarity with Rubinstein-Taybi syndrome. Proc Nat Acad Sci USA 94:10215-10220.

Toyo-oka K, Shionoya A, Gambello MJ, Cardoso C, Leventer R, Ward HL, Ayala R, Tsai L-H, Dobyns W, Ledbetter D, Hirotsune $\mathrm{S}$ and Wynshaw-Boris A (2003) 14-3-3 $\varepsilon$ is important for neuronal migration by binding to NUDEL: A molecular explanation for Miller-Dieker syndrome. Nat Genet 34:274-285.

Vermot J, Niederreither K, Garnier J-M, Chambon P and Dolle P (2003) Decreased embryonic retinoic acid synthesis results in a DiGeorge syndrome phenotype in newborn mice. Proc Nat Acad Sci 100:1763-1768.

Vitelli F and Baldini A (2003) Generating and modifying DiGeorge syndrome-like phenotypes in model organisms: Is there a common genetic pathway? Trends in Genet 19:588593.

Wagner K-D, Wagner N, Vidal VP, Schley G, Wilhelm D, Schedl A, Englert C and Scholz H (2002) The Wilms' tumor gene $W t 1$ is required for normal development of the retina. EMBO J 21:1398-1405.

Walkey CJ, Donohue LR, Bronson R, Agellon LB and Vance DE (1997) Disruption of the murine gene encoding phosphatidylethanolamine $N$-methyltransferase. Proc Natl Acad Sci USA 94:12880-12885.

Walz K, Caratini-Rivera S, Bi W, Fonseca P, Mansouri DL, Lynch J, Vogel H, Noebels JL, Bradley A and Lupski JR (2003) Modeling $\operatorname{del}(17)(\mathrm{p} 11.2 \mathrm{p} 11.2) \quad$ and dup(17)(p11.2p11.2) contiguous gene syndromes by chromosome engineering in mice: Phenotypic consequences of gene dosage imbalance. Mol Cell Biol 23:3646-3655.

Walz K, Spencer C, Kaasik K, Lee CC, Lupski JR and Paylor R (2004) Behavioral characterization of mouse models for Smith-Magenis syndrome and $\operatorname{dup}(17)(\mathrm{p} 11.2 \mathrm{p} 11.2)$ Hum Mol Genet 13:367-378.

Wells DJ, Wells KE, Asante EA, Turner G, Sunada Y, Campbell KP, Walsh FS and Dickson G (1995) Expression of human full-length and minidystrophin in transgenic $m d x$ mice: Implications for gene therapy of Duchenne muscular dystrophy. Hum Mol Genet 4:1245-1250.

Wilson MG, Towner JW, Coffin GS, Ebbin AJ, Siris E and Brager P (1981) Genetic and clinical studies in 13 patients with the Wolf-Hirschhorn syndrome [del(4p)]. Hum Genet 59:297307.

Xue Y, Gao X, Lindsell CE, Norton CR, Chang B, Hicks C, Gendron-Maguire M, Rand EB, Weinmaster G and Gridley $\mathrm{T}$ (1999) Embryonic lethality and vascular defects in mice 
lacking the Notch ligand Jagged1. Hum Mol Genet 8:723730 .

Yagi H, Furutani Y, Hamada H, Sasaki T, Asakawa S, Minoshima S, Ichida F, Joo K, Kimura M, Imamura S, Kamatani N, Momma K, Takao A, Nakazawa M, Shimizu N and Matsuoka R (2003) Role of $T B X 1$ in human del22q11.2 syndrome. Lancet 362:1366-1373.

Yan J, Walz K, Nakamura H, Carattini-Rivera S, Zhao Q, Vogel H, Wei N, Justice MJ, Bradley A and Lupski JR (2003) COP9 signalosome subunit 3 is essential for maintenance of cell proliferation in the mouse embryonic epiblast. Mol Cell Biol 23:6798-6808.

Yan M, Wang H, Chan B, Roose-Girma M, Erickson S, Baker T, Tumas D, Grewal IS and Dixit VM (2001) Activation and accumulation of $\mathrm{B}$ cells in TACI-deficient mice. Nat Immunol 2:638-643.

Yang T, Adamson TE, Resnick JL, Leff S, Wevrick R, Francke U, Jenkins NA, Copeland NG and Brannan CI (1998) A mouse model for Prader-Willi syndrome imprinting-centre mutations. Nat Genet 19:25-31.
You Y, Bergstrom R, Klemm M, Lederman B, Nelson H, Ticknor C, Jaenisch R and Schimenti J (1997) Chromosomal deletion complexes in mice by radiation of embryonic stem cells. Nat Genet 15:285-288.

Yu RN, Ito M, Saunders TL, Camper SA and Jameson JL (1998) Role of Ahch in gonadal development and gametogenesis. Nat Genet 20:353-357.

Yu Y and Bradley A (2001) Engineering chromosomal rearrangements in mice. Nat Rev Genet 10:780-790.

Zhang P, Liegeois NJ, Wong C, Finegold M, Hou H, Thompson JC, Silverman A, Harper JW, DePinho RA and Elledge SJ (1997) Altered cell differentiation and proliferation in mice lacking p57KIP2 indicates a role in Beckwith-Wiedemann syndrome. Nature 387:151-158.

Zheng B, Mills AA and Bradley A (1999) A system for rapid generation of coat color-tagged knockouts and defined chromosomal rearrangements in mice. Nucleic Acids Res 27:2354-2360.

Editor Associado: Angela M. Vianna-Morgante 